\title{
Ichnocoenoses from the Carboniferous of eastern Canada and their implications for the recognition of ichnofacies in nonmarine strata
}

\author{
Dave G. Keighley ${ }^{1}$ and Ron K. Pickerill ${ }^{2}$ \\ 1. New Brunswick Department of Natural Resources, PO Box 6000, \\ Fredericton, New Brunswick, Canada E3B 5H1. <dave.keighley@gnb.ca> \\ 2. Department of Geology, University of New Brunswick, Fredericton, New Brunswick, Canada E3B 5A3
}

Date received:April 10, 2002 I Date accepted:May 2, 2003

\begin{abstract}
Sixty-six suites of trace fossils from thirty-four different localities were collected or observed in the Carboniferous Mabou and Cumberland groups of western Cape Breton Island. Recurrent suites have been compiled into thirteen ichnocoenoses. Twelve of these ichnocoenoses, together with others from the Carboniferous elsewhere in the Maritimes, can be considered representative of two revised ichnofacies and their related composite ichnofacies. The remaining ichnocoenosis is currently anomalous.

In our view, some ichnofacies identified in the nonmarine realm have been too broadly defined. They allow for the inclusion of ichnocoenoses that are better considered representatives of composite ichnofacies. The Mermia ichnofacies is thus emended to consist primarily of systematic-coverage interface burrows and trails, irregular interface burrows and trails, non-striate pits, sinusoidal burrows and trails, migrating burrows, systematic-coverage burrow networks, (dense coverage) simple burrows and, if present, subordinate trackways. It remains an ichnofacies indicative of quiet water, oxygenated, permanently subaqueous conditions with significant organic input. Two Cape Breton Island ichnocoenoses are representative of the revised Mermia ichnofacies. The Scoyenia ichnofacies is emended to consist primarily of bilobate or striate pits and trails, trackways, meniscate burrows, (sparse coverage) simple burrows and, if present, subordinate vertical burrows. It remains an ichnofacies indicative of transitional environments, specifically quiet water conditions that regularly dry out, or periodically inundated floodplains. Four Cape Breton Island ichnocoenoses are representative of the revised Scoyenia ichnofacies.

Six ichnocoenoses from Cape Breton Island contain some trace fossils considered typical of both the Mermia and Scoyenia ichnofacies as emended. Two interpretations are possible. These ichnocoenoses might indicate instances where the trace-fossil producers were environmentally tolerant animals that could inhabit and behave similarly in either setting. Alternatively, they may represent cases where producers active in different environments had their traces juxtaposed or even overprinted due to a change in environmental conditions. In this latter case, the ichnocoenoses can be considered examples of composite ichnofacies that are taphonomic successors of combinations of the Mermia, Scoyenia, and the well-established Skolithos ichnofacies.
\end{abstract}

\section{RÉSUMÉ}

Soixante-six ensembles d'ichnofossiles de 34 emplacements différents ont été prélevés ou observés dans les groupes carbonifères de Mabou et de Cumberland dans l'ouest de l'île du Cap-Breton. Les ensembles répétitifs ont été compilés au sein de 13 ichnocoenoses. Douze de ces ichnocoenoses, auxquelles on peut ajouter les autres exemplaires du Carbonifère présents ailleurs dans les Maritimes, peuvent être considérées comme des types représentatifs de deux ichnofaciès révisés et de leurs ichnofaciès composites connexes. Les autres ichnocoenoses constituent actuellement des types anomaux.

À notre avis, certains ichnofaciès insérés dans le domaine non marin ont été définis d'une façon trop sommaire. Ils permettent l'inclusion d'ichnocoenoses davantage considérées comme des types représentatifs d'un ichnofaciès composite. Il faut ainsi corriger l'ichnofaciès Mermia en le décrivant comme un ichnofaciès principalement constitué de tubes et de pistes de reptation à interface de couverture systématique, de tubes et de pistes de reptation à interface irrégulière, d'alvéoles non striées, de tubes et de pistes de reptation sinusoïdales, de tubes de migration, de réseaux de tubes à couverture systématique, de tubes simples (à couverture dense) et, le cas échéant, de chemins secondaires. Il demeure un ichnofaciès témoignant d'eau calme, d'oxygénation et d'un milieu en permanence subaquatique, avec apport organique substantiel. Deux ichnocoenoses de l'île du Cap-Breton sont représentatives des ichnofaciès Mermia révisés. L'ichnofaciès Scoyenia corrigé est principalement constitué d'alvéoles et de pistes de reptation bilobées ou striées, de chemins, de tubes méniscaux, de tubes simples (à couverture éparse) et, le cas échéant, de tubes verticaux subordonnés. Il demeure un ichnofaciès révélateur d'environnements de transition, et plus précisément de milieux

Atlantic Geology 39, 1-22 (2003)

0843-5561|03|03001-22\$4.30|0 
d'eau calme s'asséchant régulièrement ou de plaines d'inondation périodiquement inondées. Quatre ichnocoenoses de l'île du Cap-Breton sont représentatives de l'ichnofaciès révisé Scoyenia.

Six ichnocoenoses de l’île du Cap-Breton renferment quelques ichnofossiles considérés comme des éléments caractéristiques des ichnofaciès Mermia et Scoyenia corrigés. Deux interprétations sont possibles. Ces ichnocoenoses pourraient correspondre à des cas où les producteurs d'ichnofossiles constituaient des animaux tolérants de l'environnement qui pouvaient habiter dans l'un ou l'autre milieu et se comporter de façon semblable. D'un autre côté, ils pourraient représenter des cas où des producteurs actifs dans des environnements différents ont juxtaposé leurs traces ou encore les ont superposées en raison d'une modification des conditions environnementales. Dans ce dernier cas, les ichnocoenoses peuvent être considérées comme des exemples d'ichnofaciès composites constituant des successeurs taphonomiques de combinaisons de l'ichnofaciès Mermia, du Scoyenia et de l'ichnofaciès reconnu Skolithos.

\section{INTRODUCTION}

In a facies context, the observation of features such as sedimentary structures and lithologies leads to an interpretation of the controls (sediment supply, depositional process, climate, water chemistry, etc.), and thence of the sedimentary environment in which the features formed (Middleton 1978; Reading 1978). The behaviour (ethology) of faunas on or in a sediment body is preserved in the rock record as biogenic sedimentary structures, or trace fossils. Ethology is directly influenced by many of the same environmental controls noted above. Accordingly, trace fossils can be treated in a facies context to provide evidence of their depositional (rarely erosional) sedimentary setting.

In this paper, we discuss the occurrence of trace fossils from many different nonmarine strata of the Mabou and Cumberland groups (Carboniferous) of western Cape Breton Island (Figs. 1, 2) with respect to the depositional setting in which they are interpreted to have formed. These trace fossils were detailed systematically by Keighley and Pickerill (1997, 1998). We then comment on the implications of our observations for the modelling of trace fossil associations in nonmarine depositional settings on a global scale.

\section{TERMINOLOGY}

General ichnological terms follow our earlier usage (Keighley and Pickerill 1994, 1996a, 1997, 1998; Pickerill 1994). However, in providing working models for the occurrence of trace fossils in particular depositional settings, numerous additional terms have been proposed by other workers. As Bromley $(1990,1996)$ has noted, these terms have far from uniform usage. Therefore, we first detail how these terms are applied in this paper.

\section{Ichnospecies, ichnogenera, and higher level nomenclature}

Different trace-fossil morphologies are identified and named as distinct ichnospecies. Trace fossils with only subtle morphological differences, representing slight ethological variation on the part of the producer, are grouped together within ichnogenera, but no formally accepted higher level of organization is in common or universally accepted use (Pickerill 1994). However, in a sediment body there may be a wide variety of organisms behaving sufficiently differently

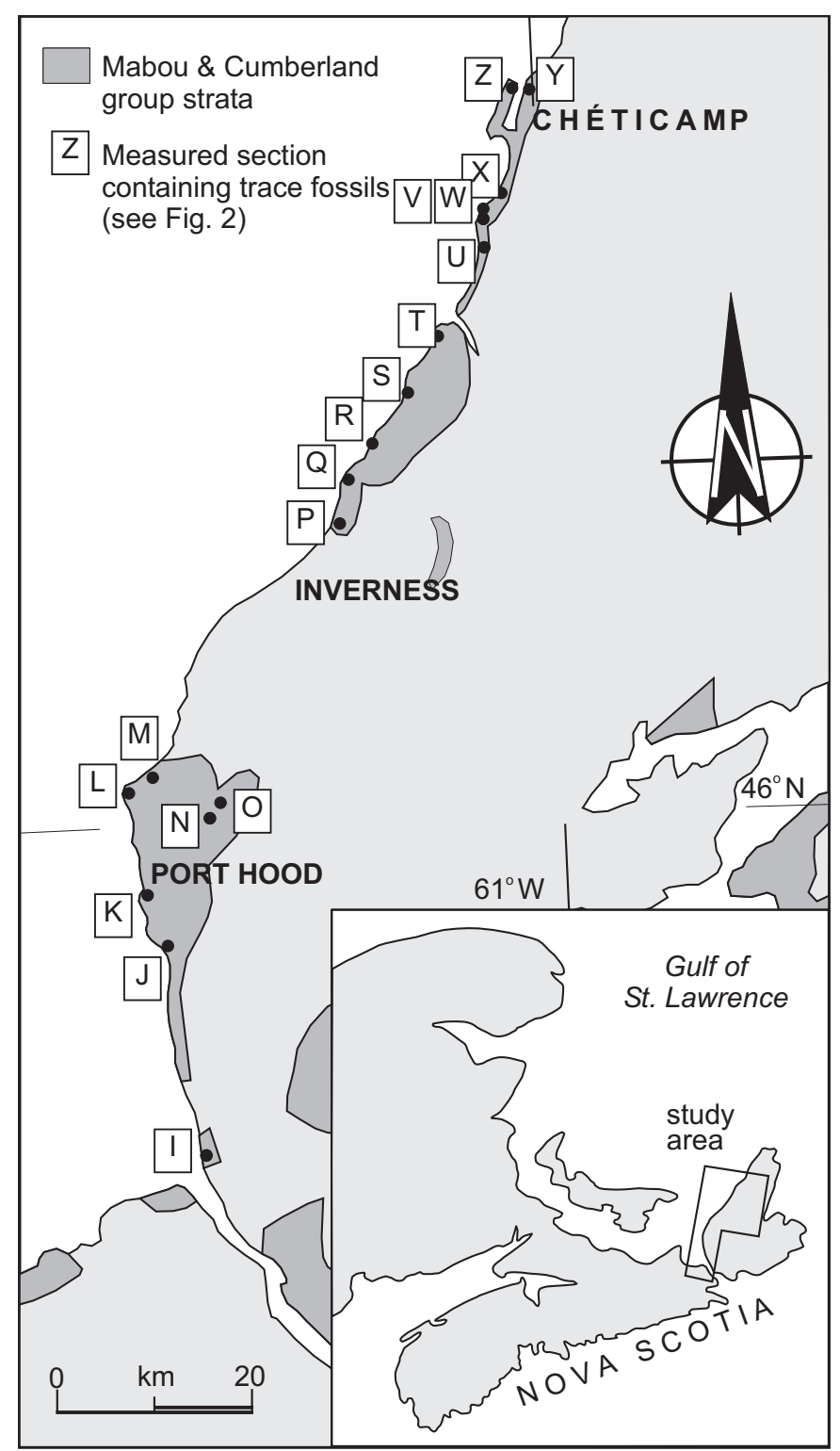

Fig. 1 General geological map of the study area and location of sections (Fig. 2) containing trace fossils used in this study.

to produce a plethora of ichnogenera and so, to facilitate discussion, informal higher level groupings are commonly used for morphologically similar trace fossils (e.g., Table 1). For comparative purposes, morphological groupings are useful because of the many nomenclatural problems that have yet to be resolved for several individual ichnotaxa. Groupings also 


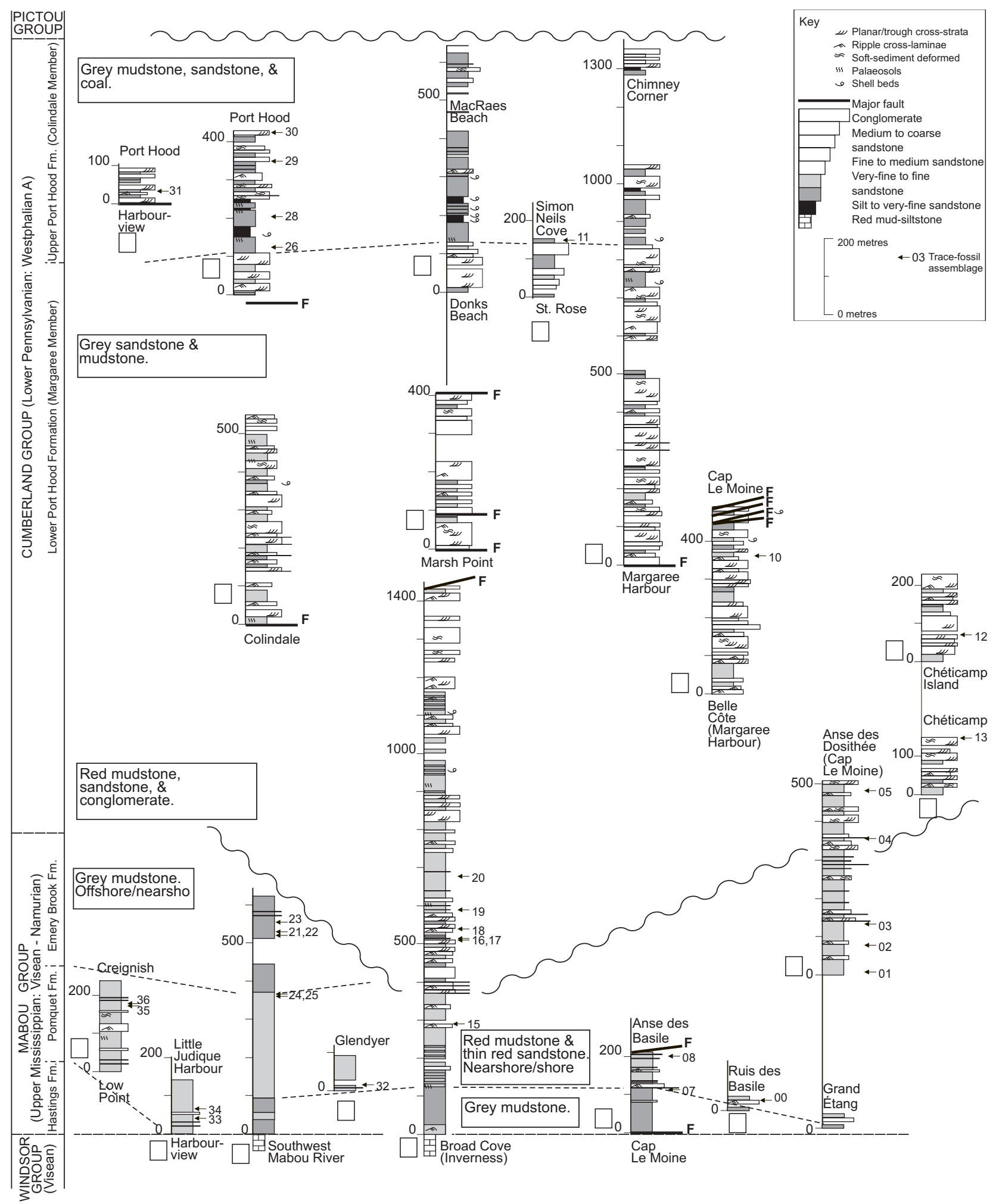

Fig. 2 Lithostratigraphy of ichnocoenoses recovered from the Pennsylvanian of western Cape Breton Island. 
Table 1. Morphological groupings of trace fossils as used in this contribution. The example trace fossils used include those encountered in western Cape Breton Island and those used by Buatois and Mángano $(1995,1998)$ to define the Mermia- and Scoyenia ichnofacies. The morphological groups are established from comparison of the diagnoses of these trace fossils.

Morphological grouping

I. Systematic-coverage branching burrow networks

II. Migrating burrows

III. Simple systematic-coverage interface burrows/trails (incl. looping trails, crossing trails)

IV. Simple irregular interface burrows/trails (nonbilobate)

V. Simple non-striate pits (non-bilobate)

VI. Sinusoidal interface burrows/ trails (incl. zig-zag trails)

VII. Simple burrows

VIII. Trackways (vertebrate/invertebrate)

IX. Systematic coverage spreiten/spreiten-like burrows

X. Striate/bilobate pits

XI. Longitudinally divided burrows/trails (bilobate, trilobate)

XII. Simple meniscate/pelleted burrows

XIII. Vertical burrows

XIV. Vertical (sediment) displacement shafts

XV. Branching burrow networks ( \pm walls, \pm chambers)

XVI. Vertical aspect J- shaped and spiral burrows
Example trace fossil

Paleodictyon Meneghini, Vagorichnus Buatois et al.

Phycodes Richter, Treptichnus Miller

Circulichnus Vialov, Gordia Emmons (incl. Mermia), Haplotichnus Miller, Spirodesmos Andree

Helminthopsis Heer, Helminthoidichnites Fitch, Paracanthorhaphe Wu, Tuberculichnus Ksiazkiewicz, "thin irregular trails", "fine sinuous trails", "irregularly meandering trails"

Conichnus Myannil, Lockeia James, Margaritichnus Bandel, "small ovate pits, type C"

Cochlichnus Hitchcock, Plangtichnus Miller, Undichnus Anderson

Palaeophycus Hall, Planolites Nicholson

Diplichnites Dawson, Hexapodichnus Hitchcock, Laoporus Lull, Orchesteropus Frenguelli, Monomorphichnus Crimes, Protichnites Owen, Pterichnus Hitchcock, Stiallia Smith, "appendage marks", "vertebrate trackways"

Fuersichnus Bromley \& Asgaard, Rhizocorallium Zenker, Spirophyton Hall

Gluckstadtella Savage, Rusophycus Hall, Selenichnites Romano \& Whyte, "small stuffed burrows", "small ovate pits, types A and B", "plug-shaped burrows", "arthropod resting traces"

Aulichnites Fenton \& Fenton, Cruziana d'Orbigny, Didymaulichnus Young, Diplopodichnus Brady, Scolicia Quatrefages

Beaconites Vialov, Scoyenia White, Taenidium Heer

Arenicolites Salter, Skolithos Haldemann, Tigillites Rouault

Vertical "escape" burrows

Ophiomorpha Lundgren, Spongeliomorpha Saporta, Thalassinoides Ehrenberg

Ichnogyrus Bown \& Kraus, Scaphichnium Bown and Kraus permit analysis and use of present-day traces that currently cannot be assigned ichnotaxonomical names (I.C.Z.N. 1985, Article 1a). Use of morphotypes as opposed to ethological categories (contra Seilacher 1964; Frey and Seilacher 1980; Lockley et al. 1987; and others) is also preferable because of the subjective nature of ethologic categories (Keighley and
Pickerill 1996a). For instance, in grouping traces into ethological categories, Buatois and Mángano $(1995,1998)$ considered Cochlichnus to be a grazing trace. Although this interpretation is likely for some examples, other specimens of Cochlichnus are better interpreted as locomotion traces (e.g., Elliott 1985). 


\section{Trace-fossil assemblages, trace-fossil suites, and tiering}

According to Bromley (1990), an assemblage is the basic objective term that embraces all the trace fossils occurring within a single rock unit (single bed, bed couplet, or recurrent interbeds) irrespective of whether or not the traces were produced simultaneously or as temporally separate bioturbation events. Where an assemblage can be shown to have been produced by temporally separate events, it can be subdivided into component trace-fossil suites, for example, where a burrow and a boring cross-cut in a sedimentary rock (pre-omission and post-omission suites, Bromley 1990) or where hypichnial and epichnial trackways occur on a sheetflood sandstone bed (predepositional and postdepositional suites, Han and Pickerill 1994). Although a uniform database of suites is the ideal aim, the nature of the ichnofossil record means that, as in this work, the distinction of suites is not always possible. Suites are herein preferred to the "eco-stratification" definition of "tiers" as provided by Ausich and Bottjer (1982). Inherent in the definition of tiers is the contention that the different members of an ecosystem and their produced traces are all present simultaneously, although they may be partitioned into different (benthic) habitats (e.g., epifaunal, shallow infaunal, and deep infaunal tiers). This cannot be demonstrated reliably in ancient strata.

It would be unusual for only one organism to have been present and to have produced only one trace on or within a sedimentary unit. However, due to taphonomic factors, only one trace fossil may have been identified from that unit. Accordingly, an assemblage or suite need not contain more than one trace fossil.

\section{Ichnocoenoses and ichnofacies}

Seilacher's (1964, p. 306) original English definition of the term "ichnocoenoses" was simply as "trace associations", and was derived from the Latin "ichnos" = trace; Greek "koinos", latinization "coenos" = "shared" or "common"; and Greek "osis", latinization "-osis" = possession of a particular quality. It is an objective term and can be related to our use of suite and assemblage. Specifically, where suites contain similar trace fossils, and the additional caveats of similar preservation, host rock type, and stratigraphic succession, they can be considered as belonging to the same ichnocoenosis. These additional caveats should be included when the reason for identifying ichnocoenoses is their application in ichnofacies analysis (see below), because the caveats help address the concerns of Goldring $(1993,1995)$ regarding the interpretations of depositional setting that can realistically be gleaned from ichnofacies.

The term ichnocoenosis has also been used to mean "community" (e.g., Dörjes and Hertweck 1975) although, originally, reference to "community" was limited to a comparison with body fossils, against which trace fossils "...form a more adequate record of the original benthic communities..." (Seilacher
1964, p. 306). Numerous authors adopted this "community" approach to the definition (e.g., Bromley and Asgaard 1979), or even a "simultaneous community" approach (Ekdale et al. 1984; Ekdale 1985). However, Pickerill (1992) noted that a community could never be conclusively demonstrated in the fossil record. Other authors adopted the "single depositional setting" approach to the definition (e.g., Frey and Pemberton 1985; Pickerill 1992), although this again is as subjective as the accompanying lithofacies interpretation.

Seilacher (1964, p. 303) aimed to recognize “...general trace associations, or types of ichnocoenoses, representing certain facies with a long geologic range." The result was his original ichnofacies model. When his examples were "...grouped according to their lithofacies" (Seilacher 1964, p. 313), he noted that similar ichnocoenoses, regardless of location or age, displayed "...parallel differences in lithology and inorganic sedimentary structures.” (Seilacher 1964, Fig. 7). Four groups were originally identified (the Skolithos, Cruziana, Zoophycos, and Nereites ichnofacies - following Bromley 1996, we do not italicize ichnofacies). At that time, the physical sedimentary structures, and hence by extension the ichnofacies, were interpreted as reflecting specific palaeobathymetric marine settings (littoral, shelf, slope, and abyssal respectively) although this interpretation has been superseded (Frey et al. 1990). Seilacher (1964, p. 314) concluded that “....New discoveries have meanwhile confirmed this classification and its environmental interpretation.” This comment emphasizes that the original definition was based on the observation of recurrent and descriptive trace-fossil ichnocoenoses. Implicit is an accompanying interpretation of environmental controls and palaeodepositional settings. The methodology was therefore very much in keeping with that advocated for the construction of facies in general (e.g., Middleton 1978, Reading 1978).

Other ichnofacies have been proposed that contain temporal, environmental, or depositional-setting restrictions in their definition. For example, Lockley et al. (1994) defined the morphologically similar, chronologically distinct, Palaeozoic Laoporus ichnofacies and Mesozoic Brasilichnium ichnofacies. Although such ichnofacies may be useful in some investigations, they have different limitations to Seilacher's (1963, 1964) original four morphological ichnofacies. Therefore, they cannot then be used in conjunction with, or compared with the morphological ichnofacies, or used for further interpretation of depositional setting. If environmentally defined ichnofacies were used alongside morphological ichnofacies, circular and model-driven reasoning is adopted whereby an interpretation of depositional setting is used in the definition of an ichnofacies, and the ichnofacies is then used for interpretation of depositional setting. Similarly, when the purpose of identifying ichnocoenoses is for ichnofacies modelling, only the descriptive definition of an ichnocoenosis can be used. If considerations of depositional setting or community are utilized to construct ichnocoenoses, they become interpretive ichnocoenoses: they are not equivalent or comparable to the descriptive ichnocoenoses used by Seilacher (1964). 
Table 2. Ichnocoenoses of the Mabou and Cumberland groups, western Cape Breton Island, Nova Scotia, eastern Canada. Trace fossils were encountered at various localities in western Cape Breton Island (Figs. 1,2). Individual assemblages are designated by the epithet TF followed by a two figure number. Additional letters represent the various suites identified in the assemblage. A complete suite number, for example, would be "TF09a" (note that no suites from localities TF06, TF09, and TF14 exist, as the material is now considered nonbiogenic). Similar suites from similar strata and with similar preservation are included in the same ichnocoenosis.

\begin{tabular}{|c|c|c|c|c|}
\hline Ichnocoenosis & Morphotypes & Trace fossils encountered & Preservation of trace fossils & $\begin{array}{c}\text { Interpretated } \\
\text { depositional setting }\end{array}$ \\
\hline $\begin{array}{c}\text { A } \\
\text { (6 suites: } \\
\text { TF21a, TF21b, TF21c, } \\
\text { TF22a, TF22b, and } \\
\text { TF23a) }\end{array}$ & $\begin{array}{l}\text { Simple burrows, Striate } \\
\text { surface pits. }\end{array}$ & $\begin{array}{l}\text { Planolites beverleyensis, } \\
\text { Rusophycus carbonarius }\end{array}$ & $\begin{array}{l}\text { Epirelief and full relief endichnial, within or upon } \\
\text { thin, horizontally laminated, very-fine- or fine- } \\
\text { grained grey sandstones that are cyclically } \\
\text { interlaminated to interbedded with dark grey } \\
\text { siltstones. }\end{array}$ & Quiet water lacustrine. \\
\hline $\begin{array}{c}\text { C } \\
\text { (3 suites: } \\
\text { TF00a, TF25a, and } \\
\text { TF25b; ?+1 other, } \\
\text { TF07a) }\end{array}$ & $\begin{array}{l}\text { Bilobate trails, } \\
\text { Simple interface trails, } \\
\text { Striate surface pits. }\end{array}$ & $\begin{array}{l}\text { Cruziana problematica } \\
\text { Helminthopsis hieroglyphica } \\
\text { Rusophycus carbonarius } \\
\text { cf. Rusophycus carbonarius } \\
\text { plug-shaped burrows }\end{array}$ & $\begin{array}{l}\text { Epirelief and full relief epichnial, on bedding surfaces } \\
\text { within units of red and mottled red and grey, very- } \\
\text { fine- and fine-grained sandstones that are wave } \\
\text { rippled (wavelength between crests }=30-40 \mathrm{~mm} \text { ). }\end{array}$ & $\begin{array}{l}\text { Wave agitated, } \\
\text { moderate energy } \\
\text { lacustrine } \\
\text { (nearshore/shoreline). }\end{array}$ \\
\hline $\begin{array}{c}\text { F } \\
\text { (5 suites: } \\
\text { TF02a, TF03c, TF03d, } \\
\text { TF03e, and TF15a) }\end{array}$ & $\begin{array}{l}\text { Bilobate trails, } \\
\text { Striate surface pits, } \\
\text { Simple interface trails, } \\
\text { Systematic-coverage trails, } \\
\text { Trackways (invertebrate). }\end{array}$ & $\begin{array}{l}\text { Diplopodichnus biformis } \\
\text { interface trails (types A, B, and C) } \\
\text { Circulichnus montanus } \\
\text { cf. Circulichnus montanus } \\
\text { Gordia marina } \\
\text { Gluckstadtella cooperi } \\
\text { Protichnites isp., (type C) } \\
\text { appendage marks (type A) } \\
\text { small ovate pits (type A) }\end{array}$ & $\begin{array}{l}\text { Epichnial (epirelief and full relief) on variably thick } \\
\text { mudstone or siltstone that drape current-rippled } \\
\text { sandstones (or as counterpoint hypichnia on } \\
\text { overlying laminated red siltstone). }\end{array}$ & $\begin{array}{l}\text { Floodplain, } \\
\text { ephemeral ponds. }\end{array}$ \\
\hline $\begin{array}{c}\text { G } \\
\text { (3 suites: } \\
\text { TF03a, TF03f, and } \\
\text { TF03g; ?+1 other, } \\
\text { TF35a) }\end{array}$ & Simple meniscate burrows. & $\begin{array}{l}\text { Taenidium barretti } \\
\text { cf. Taenidium barretti }\end{array}$ & $\begin{array}{l}\text { Endichnial in (climbing-) current-rippled, } \\
\text { occasionally (desiccation-) cracked sandstones that } \\
\text { interbed with horizontally laminated mudstones and } \\
\text { siltstones that contain palaeosols and nodular } \\
\text { horizons of calcite. }\end{array}$ & Floodplain. \\
\hline
\end{tabular}


Table 2. (Contd.)

\begin{tabular}{|c|c|c|c|c|}
\hline Ichnocoenosis & Morphotypes & Trace fossils encountered & Preservation of trace fossils & $\begin{array}{c}\text { Interpretated } \\
\text { depositional setting }\end{array}$ \\
\hline $\begin{array}{c}\mathrm{H} \\
\text { (6 suites: } \\
\text { TF04a, TF17a, TF17b, } \\
\text { TF17c, TF17d, and } \\
\text { TF17e) }\end{array}$ & $\begin{array}{l}\text { Bilobate trails, } \\
\text { Striate surface pits. }\end{array}$ & $\begin{array}{l}\text { Cruziana problematica } \\
\text { cf. Cruziana problematica } \\
\text { Rusophycus carbonarius } \\
\text { cf. Rusophycus carbonarius } \\
\text { small ovate pits (type B) }\end{array}$ & $\begin{array}{l}\text { Hypichnial, alongside tool marks, on the base of }<1.5 \\
\mathrm{~m} \text { thick, red (grey at the base), current rippled (plus } \\
\text { rare basal cross-strata), poorly sorted, fine-grained } \\
\text { sandstone and siltstone beds that overlie red } \\
\text { mudstone (rarely with raindrop imprints, palaeosols, } \\
\text { and desiccation cracks). }\end{array}$ & $\begin{array}{l}\text { Ephemeral fluvial } \\
\text { channel. }\end{array}$ \\
\hline $\begin{array}{c}\text { I } \\
\text { (6 suites: } \\
\text { TF12a, TF13a, TF18a, } \\
\text { TF18b, TF18c, and } \\
\text { TF30a; + ?1 other, } \\
\text { TF05a) }\end{array}$ & $\begin{array}{l}\text { Bilobate trails, } \\
\text { Simple burrows, } \\
\text { Simple interface trails. }\end{array}$ & $\begin{array}{l}\text { Didymaulichnus cf. lyelli } \\
\text { Helminthopsis hieroglyphica } \\
\text { Palaeophycus striatus } \\
\text { cf. Palaeophycus }\end{array}$ & $\begin{array}{l}\text { Epichnia and endichnia associated with parting } \\
\text { surfaces (occasionally with parting lineations) within } \\
\text { thick (up to } 10 \mathrm{~m} \text { ), low angle, cross-stratified } \\
\text { sandstones and within (mostly the troughs of ripples } \\
\text { in) ?wave-rippled sandstones. }\end{array}$ & $\begin{array}{l}\text { Perennial fluvial } \\
\text { channel, with in- } \\
\text { channel dunes. }\end{array}$ \\
\hline $\begin{array}{c}\text { K } \\
\text { (1 suite: } \\
\text { TF26a) }\end{array}$ & Non-striate pits. & Conichnus isp. & $\begin{array}{l}\text { Hyporelief on } 30-60 \mathrm{~mm} \text { thick beds of horizontally } \\
\text { laminated to undulatory (?current) rippled, very fine- } \\
\text { grained sandstone interbedded with grey mudstone. }\end{array}$ & $\begin{array}{l}\text { Floodplain lake, pre- } \\
\text { storm deposit. }\end{array}$ \\
\hline $\begin{array}{l}\mathrm{L} \\
\text { (1 suite: } \\
\text { TF26b) }\end{array}$ & Sinusoidal trails. & $\begin{array}{l}\text { Cochlichnus anguineus } \\
\text { Cochlichnus isp. } \\
\text { Undichnus binus } \\
\text { Undichnus consulcus }\end{array}$ & $\begin{array}{l}\text { Epirelief (and ?full relief epichnia) on a } 30 \mathrm{~mm} \text { thick } \\
\text { bed of horizontally laminated to undulatory } \\
\text { (?current) rippled, very-fine-grained sandstone } \\
\text { interbedded with grey mudstone that lacks evidence } \\
\text { of subaerial exposure. }\end{array}$ & $\begin{array}{l}\text { Floodplain lake, post- } \\
\text { storm deposit. }\end{array}$ \\
\hline
\end{tabular}

\section{ICHNOCOENOSES FROM THE CARBONIFEROUS OF CAPE BRETON ISLAND}

The present work stems from a study of sixty-six suites of trace fossils from thirty-four localities in the Mabou and Cumberland groups (Keighley and Pickerill 1997, 1998; Figs. $1,2)$. Detailed descriptions and photographs of the trace fossils discussed herein are provided in Keighley and Pickerill $(1997,1998)$. A catalogue of the trace fossils observed in every suite, along with $~ 1: 1000$ sedimentary logs illustrating their stratigraphic occurrence in the $\sim 4 \mathrm{~km}$ of measured sections, is included in Keighley (1996, unpublished $\mathrm{PhD}$ thesis).

The suites represent 13 ichnocoenoses, named A to $\mathrm{M}$ (Table 2) and described below. Figs. 3-6 are cartoons (not to scale) illustrating most of the typical trace fossils in each ichnocoenosis. Fig. 2 summarizes the general depositional setting(s) of each formation containing trace fossils as interpreted by earlier workers (referenced in Gibling 1995, Keighley and Pickerill 1996b). These general interpretations form the basis of the more specific interpretation of depositional setting given for each ichnocoenosis described below.

\section{Ichnocoenosis A (Table 2, and Fig. 3)}

The six suites represented by this ichnocoenosis comprise simple small burrows of Planolites beverleyensis (Billings) and striate surface pits assigned to Rusophycus carbonarius (Dawson). Similar suites have recently been noted from Cape Breton Island by Hamblin(2001). All of our material has been recovered from strata assignable to the lacustrine Emery Brook Fm., and occurs within or upon cyclically interlaminated to interbedded, thin, horizontally laminated, very-fine or finegrained grey sandstones and dark grey siltstones. These strata indicate seasonally fluctuating sediment deposition (rhythmites) in quiet water that was permanently removed from wave influence (an "offshore" lacustrine setting). The presence of 1 $\mathrm{m}$ thick, lenticular beds of cross-stratified, fine-grained sandstones in the successions immediately overlying occurrences 

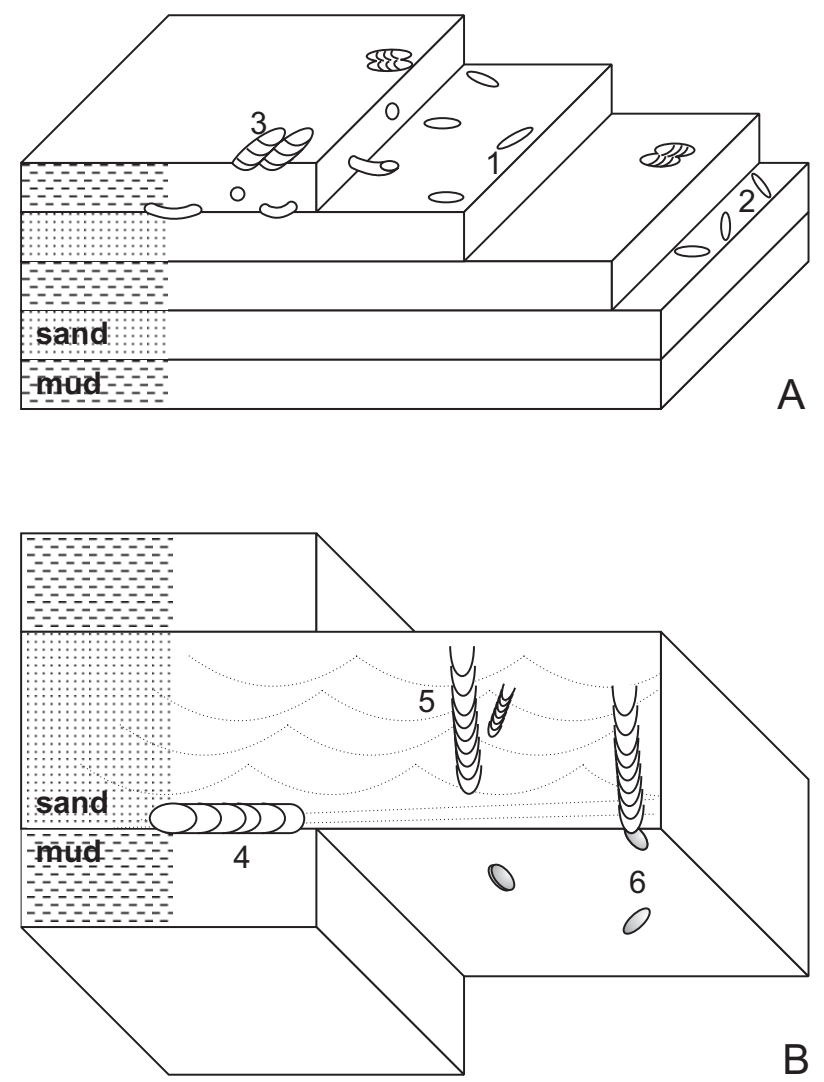

Fig. 3 Ichnocoenoses A, B, and C: examples of trace fossils and their toponomic preservation. $1=$ Planolites beverleyen sis, 2 = cf. P. beverleyensis, $3=$ Rusophycus carbonarius, $4=\mathrm{cf}$. Taenidium, $5=$ (sub-) vertical sediment displacement shafts (fugichnia), 6 = small ovate pit, type $\mathrm{C}$ (possible basal expression of the displacement shafts, cf. Lockeia), $7=$ Cruziana problematica, 8 = plug-shaped burrow, $9=$ Helminthopsis hieroglyphica. See Keighley and Pickerill $(1997,1998)$ for details.

of this ichnocoenosis indicates the onset of more proximal-toshoreline conditions.

Quiet water depositional settings promote generally stable ecosystems that are in equilibrium. Such settings allow for the accumulation of organic detritus and promote the success of deposit-feeding organisms. This equates well with the presence of Planolites beverleyensis, this trace undulating in and out of the finer grained components of the rhythmically bedded strata (Fig. 3). Planolites is typically considered produced, and probably backfilled, by a deposit-feeding organism (Keighley and Pickerill 1995). The Rusophycus carbonarius specimens in this association are, on the other hand, usually encountered within or at the base of the relatively coarser grained material; however, nowhere are the two ichnotaxa recorded cross-cutting each other. Due to their common association elsewhere with Cruziana problematica (Schindewolf), ichnospecies of Rusophycus are usually considered produced by epifaunal arthropods (Keighley and Pickerill 1996a), although no examples of Cruziana were encountered in this ichnocoenosis. Possible scenarios might have such organisms concealing themselves or hibernating during periods of slightly higher energy conditions that accompanied the deposition of the thin sands.

\section{Ichnocoenosis B (Table 2, and Fig. 3)}

The sole suite (TF24b) from near the top of the Pomquet Fm. contains full relief, hypichnial, meniscate backfilled horizontal burrows (cf. Taenidium) and subvertical shafts defined by downward displacement of primary lamination(fugichnia). Small ovate pits, hypichnially preserved as mounds, are the basal representation of the shafts. Similar almond-shaped forms with a central ridge, from storm deposits of the nonmarine Hastings Fm. in Nova Scotia, have been named as Lockeia isp. by Hamblin (2001). However, because our material is not distinctly almond shaped with a central ridge, most typical of Lockeia, and because it is uncertain whether or not these mounds represent the true base of these shafts or whether the shafts continue into the underlying stratum, no binomen is attached to them.

The preserving stratum itself is a $60 \mathrm{~mm}$ thick, very-finegrained sandstone that contains small scale wave ripples and low angle cross-laminae. Overlying beds consist of a $0.5 \mathrm{~m}$ thick mudstone, grey at the base, oxidized red toward the top, overlain by a coarsening upward, $0.3 \mathrm{~m}$ thick, pink sandstone that contains a trace-fossil suite included in ichnocoenosis $\mathrm{C}$. The host stratum is interpreted as a partially wave-reworked event deposit (lacustrine turbidite) that interrupted the normal, shallow, but quiet-water depositional regime, likely in a restricted, marginal lacustrine setting.

As with Lockeia, if the small ovate pits are the basal representation of the bioturbation, they can be interpreted as being produced by surface-feeding bivalve molluscs. Associated vertical shafts may indicate disruption of this surface feeding by a rapid sedimentation event. The established organisms, unsuited to such environmental changes, either had to relocate by displacing themselves upward, or perish (Bromley and Asgaard 1991). The meniscate burrow (cf. Taenidium) may represent a returning opportunist exploring the new substrate for food, a washed-in "doomed pioneer" (cf. Föllmi and Grimm 1990) or even an organism that did not or could not relocate. Note, therefore, that TF $24 \mathrm{~b}$ is probably best described as an 

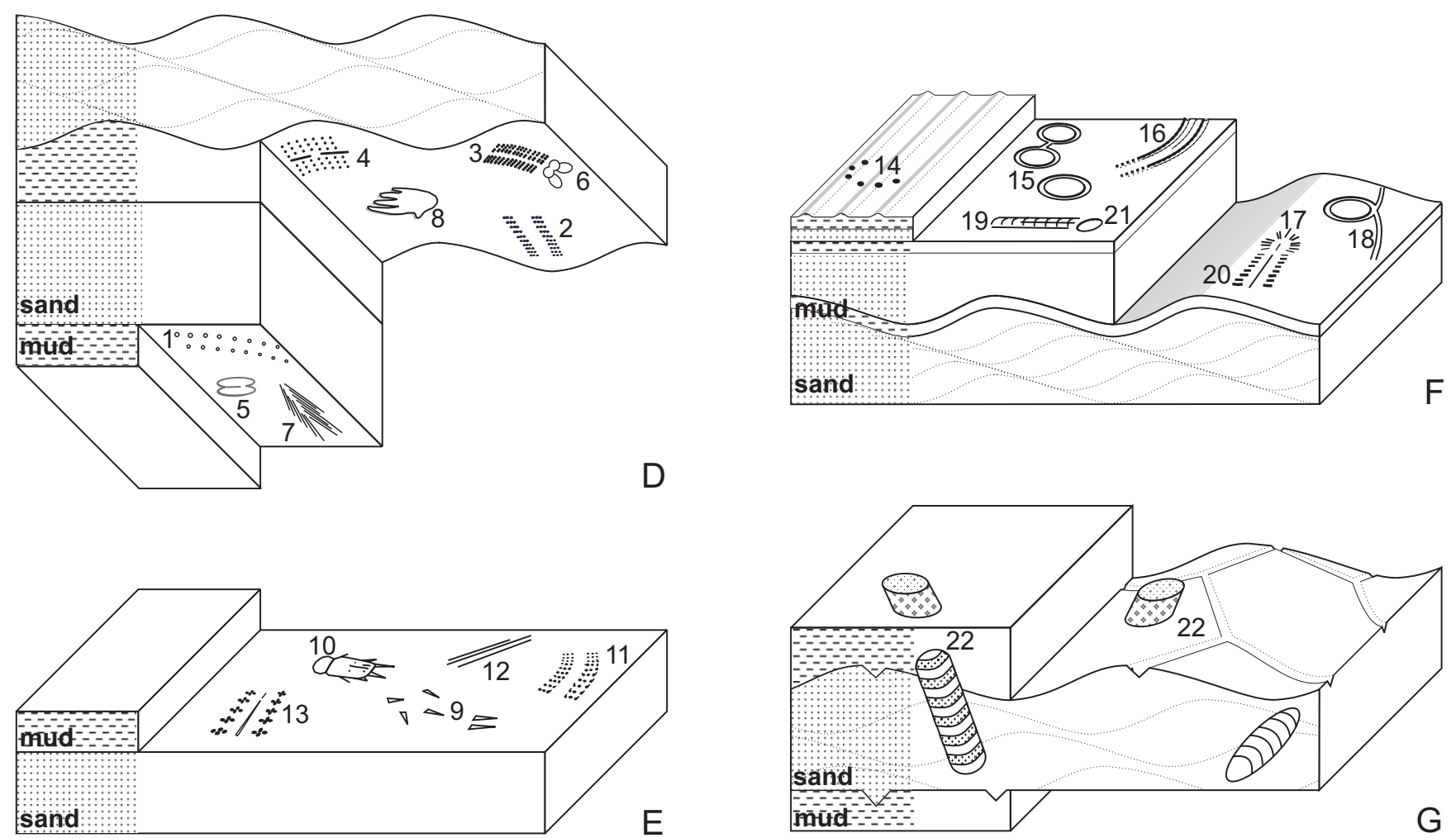

Fig. 4 Ichnocoenoses D, E, F, and G: examples of trace fossils and their toponomic preservation. 1 = Diplichnites cf. logananus, 2 =Diplichnites isp., type B, $3=$ Protichnites cf. kennediea , $4=$ Protichnites $\mathrm{cf}$. scoticus, $5=$ Rusophycus carbonarius, $6=$ Selenichnites isp., $7=$ Stiallia cf. pilosa, $8=$ vertebrate track(-way), type C, $9=$ appendage marks, type B, $10=$ arthropod "resting" trace, $11=$ Hexapodichnus horrens, 12 = Monomorphichnus $\mathrm{cf}$. lineatus, 13 = Protichnites $\mathrm{cf}$. carbonarius, 14 = appendage marks, type A, 15 = Circulichnus montanus, 16 = Diplopodichnus biformis, $17=$ Gluckstadtella cooperi, $18=$ Gordia marina, $19=$ interface trail, type A, 20 = Protichnites isp., type C, 21 = small ovate pit, type A, 22 = Taenidium barretti. See Keighley and Pickerill (1997, 1998) for details.

assemblage rather than a suite. Pre-, syn- and post-depositional suites may be represented.

\section{Ichnocoenosis C (Table 2, and Fig. 3)}

This ichnocoenosis consists of surface pits (Rusophycus carbonarius and plug-shaped burrows), bilobate and simple interface trails (Cruziana problematica and Helminthopsis hieroglyphica Heer). Examples of this ichnocoenosis occur on both round-crested (TF25a and TF25b, Keighley and Pickerill 1997, fig. 7A) and sharp-crested (TF00a, Keighley and Pickerill 1997, fig. 5C) red and mottled red-grey, very-fine- and finegrained, wave-rippled surfaces. The wavelength between the crests is 30 to $40 \mathrm{~mm}$, suggesting shallow water and small waves. The red colouration suggests contemporary or subsequent subaerial exposure and oxidation of iron-bearing minerals. TF00a is encountered adjacent to strata containing nodular calcareous concretions indicative of incipient pedogenesis. The thin, wave-rippled strata from the top of the Pomquet Fm. that host TF25a and TF25b contain mottling associated with vertical structures that may be desiccation cracks or rootlet horizons. Although the interpreted depositional setting is therefore one of "nearshore" shallow waters, the small scale of the ripples that are present indicate that the shoreface was only subject to relatively low energy conditions. No unidirectional flow structures are indicated within the preserving strata, and it is likely that the deposits accumulated slowly in a persistently wave-agitated depositional setting with relatively low net-sedimentation rates.

Unlike ichnocoenosis B, which reflects activities produced during a storm event, ichnocoenosis $\mathrm{C}$ likely represents the activity of a benthic community in an environment more persistently above wave base, possibly subaerially exposed on occasion. The proposed ecosystem would have been inhabited by deposit-feeding epibenthos (producing Rusophycus and rare Cruziana) and interface burrowers (Helminthopsis); plug-shaped burrows in TF $25 \mathrm{~b}$ are likely a preservational variant of Rusophycus.

\section{Ichnocoenosis D (Table 2, and Fig. 4)}

Trackways, including those assignable to various ichnospecies of Diplichnites, Protichnites, and Stiallia, predominate in this ichnocoenosis, with subordinate vertebrate trackways (types A, B, C, and F of Keighley and Pickerill 1998), bilobate trails (Cruziana problematica), and pits (Rusophycus isp., 
Selenichnites isp.). Suites are found in the Pomquet Fm and lower Port Hood Fm. Hamblin (2001) encountered similar vertebrate trackways, which could be part of a similar ichnocoenosis, on the base of thin sheetflood sandstones in the Hastings Formation on mainland Nova Scotia. The host strata are thin $(<0.1 \mathrm{~m})$, grey or mottled red and grey, very-fine- or fine-grained sandstones. Current ripples, occasionally subcritically climbing, are present in these mostly non-channelized strata, which are interpreted to be distal sheetflood deposits. However, all the trace fossils are preserved hypichnially on these sandstones and so they were actually produced by organisms active on the underlying strata. Underlying strata consist of thick, laminated or massive, red (rarely mottled red and grey) mudstones and thinly laminated siltstones. With the exception of rhizolithbearing mudstones associated with suite TF08a, these mudstones lack features such as palaeosols, desiccation cracks, or raindrop imprints that might indicate subaerial exposure at the time of trace-fossil production. Accordingly, it is uncertain whether the sandy sheetfloods traversed a regularly flooded plain or shallow lake. Similarly, it is conjectural whether the trace fossils were produced subaqueously or subaerially. The forms of the imprints constituting the invertebrate trackways are typically punctate or transversely striate, indicative of walking activity, but swimming (represented by Stiallia, Fig. 4, and by vertebrate trackway, type B, Keighley and Pickerill 1998) cannot be completely excluded.

A sheetflood, like a subaqueous turbidite or storm sand, is an episodic and sudden depositional event. It occurs as an aberration to prevailing environmental conditions, in this case, of general nondeposition (or very slow deposition) normally characteristic of floodplain depositional settings. The hyporelief preservation of each suite in this ichnocoenosis indicates that the trace fossils were actually produced by members of the floodplain community, the sheetflood preserving the activities of the community as a Lagerstätten.

\section{Ichnocoenosis E (Table 2, and Fig. 4)}

This ichnocoenosis is represented by five suites located in either Pomquet Fm. or lower Port Hood Fm. strata. Component trace fossils are entirely of trackways (ichnospecies of Hexapodichnus, Monomorphichnus, and Protichnites), appendage marks, and "resting" traces. They are from the same (or similar) stratigraphical successions described for ichnocoenosis $\mathrm{D}$, which are interpreted as indicative of a floodplain-sheetflood setting. However, ichnocoenosis E trace fossils have epichnial preservation, or interstratal hypichnial and epichnial preservation on and within thin, mostly tabular, horizontally laminated, micaceous sandstones. Some of these sandstones overlie soft-sediment deformed, rippled sandstone. Therefore, in contrast to ichnocoenosis $\mathrm{D}$, the producing organisms were active on a sandy substrate. Again, some marks may have been produced subaqueously, others subaerially. Some specimens of Hexapodichnus horrens Hitchcock in TF36b are present on parting surfaces within parallel-laminated sandstones and probably formed subaqueously during the flood. The arthropod "resting" trace in TF16b may have been produced by an organism that jumped, flew, or swam into a resting position. The sharp external margins of the resting and appendage marks indicate a firm cohesive substrate and, given the fine grain size, likely subaerially exposed and not waterlogged.

Although the trace fossils of this ichnocoenosis may be encountered in the same lithofacies associations as those of ichnocoenosis D, there are important differences in morphology and preservation between the suites of to the two ichnocoenoses. Also, the less diverse morphotypes of ichnocoenosis E represent more limited behavioural responses to more extreme, out of equilibrium, environmental conditions that existed at particular times within a floodplain depositional setting. Highly mobile organisms, such as the arthropods that could have produced all the trace fossils of this ichnocoenosis, are ideal for filling opportunist niches that exist on floodplains. They can relocate when conditions are unfavourable (e.g., times of flood), and quickly return to reconnoitre the environment when conditions are more favourable (e.g., during or immediately after the waning stages of a flood).

\section{Ichnocoenosis F (Table 2, and Fig. 4)}

This ichnocoenosis comprises simple interface trails (Diplopodichnus biformis Brady and types A, B, and C of Keighley and Pickerill 1997), systematic coverage trails (Circulichnus montanus Vialov, Gordia marina Emmons), and subordinate trackways (Protichnites isp.), appendage marks and a "resting" trace (Gluckstadtella cooperi Savage). All examples are from the Pomquet Fm. and occur epichnially on thin silty or muddy strata and as counterpoint hypichnia on overlying strata. These mudstones cap the same or similar sheetflood deposits described for ichnocoenosis E, and they are stratigraphically adjacent to incipient pedogenic horizons. Laterally extensive mudstone drapes can be equated with deposition of fines from still-water ponding in low-lying areas, probably following a sheetflood, behind a dammed ephemeral watercourse, or at the end point of an ephemeral river (Smith et al. 1993).

It is again speculative to interpret which traces were produced subaqueously or subaerially after standing water had disappeared. Metz (1987) illustrated that a variety of arthropod trails can be produced in ephemeral puddles. The trails that were produced subaqueously, and in water-saturated subaerial conditions, had less distinct margins than those formed in drier (but still damp) conditions (see Metz 1987, figs. 1, 15-16). Appendage marks of suite TF03d are sharp, suggesting subaerial exposure and a damp substrate at the time of formation. The varying distinctiveness between the pustulose marks that form part of the interface trails (types A-C) on TF03c (Keighley and Pickerill 1997, fig. 10) may itself reflect trails formed during different stages of substrate waterlogging. A compound Gluckstadtella-Protichnites specimen may have formed sub- 
aerially or subaqueously with an arthropod that flew or swam to this locality before alighting on the substrate. Mudstone drapes indicate the accumulation of fines and, potentially, also of organic matter in a stable setting that would encourage more systematic coverage of the sediment. Accordingly, less "opportunistic" behaviour than evidenced in ichnocoenosis E has produced trace fossils such Circulichnus and Gordia.

\section{Ichnocoenosis G (Table 2, and Fig. 4)}

All examples of this ichnocoenosis are from the Pomquet Fm. Exclusively simple meniscate burrows (Taenidium barretti (Bradshaw)) are preserved endichnially within horizontally laminated and, occasionally climbing-, current-rippled red sandstones that interbed with horizontally laminated red mudstones and siltstones. Desiccation cracks are preserved in the current-rippled sandstones hosting TF03a. Thin, but laterally persistent calcareous nodules and incipient palaeosols are numerous in all adjacent strata. Such characteristics indicate deposition of the host strata by distal sheetfloods on a subsequently dry floodplain. Some burrows exhibit downward directed, meniscate fill, but others preserve upward directed meniscate fill that can be found exichnially above the preserving bed (Keighley and Pickerill 1997, fig. 7G). Such upward directed (convex-down menisci) burrows were produced well after the actual sheetflood that produced the current-rippled sandstones in which they are now preserved. Additionally, angular fragments of the overlying strata (red mudstone) are preserved in the meniscate backfill, indicating that the overlying muds were firm and quite dry when they were biogenically reworked. Some burrows in TF03a were produced after a desiccation event because they truncate desiccation cracks.

As with ichnocoenoses D, E, and F, ichnocoenosis G can be interpreted as comprising the traces of a floodplain ecosystem. However, differences in the trace-fossil morphologies, their preservation, and lithology of the host strata require that separate ichnocoenoses be identified, since the interpretation of a "single depositional setting" is not a valid criterion for delimiting ichnocoenoses (sensu Seilacher 1964). Likewise, an interpreted "single community" approach is not a valid criterion even though the $10-20 \mathrm{~mm}$ wide Taenidium barretti of TF35a occur stratigraphically subjacent to suite TF36a (ichnocoenosis E) that contains Hexapodichnus horrens tracks of similar width. Conceivably, the burrows and tracks might have been formed by the same arthropod producer. Similarly, the Cruziana of TF03b (ichnocoenosis D) is anomalously large in comparison to our other examples of this trace fossil, but is of comparable width to the larger Taenidium burrows of TF03a, possibly indicating a common producer.

This ichnocoenosis does not comprise any of the distinctly opportunist activities interpreted for ichnocoenosis E. Instead, subaerial conditions with aerated substrates (equilibrium conditions for the floodplain) likely were required before animals undertook burrowing activities.

\section{Ichnocoenosis $\mathrm{H}$ (Table 2, and Fig. 5)}

Examples of this ichnocoenosis are found in the lowermost parts of the Port Hood Fm., preserved alongside tool marks (Keighley and Pickerill 1997, fig. 3A) on the base of fine- to very-fine-grained sandstones. The sandstones are red, rarely grey or mottled grey at the base, current rippled, locally crossstratified at the base, often with soft-sediment deformation. Sandstones are lenticular in cross-section, truncating down into predominantly red-brown laminated mudstones with incipient pedogenic features. The host strata are considered deposits of marginal or distal, ephemeral and shallow fluvial channels that had pronounced seasonal fluctuations in discharge, and which traversed a frequently subaerially exposed floodplain (Keighley and Pickerill 1996b). Tool marks predate trace production; incipient load structures postdate trace production (Keighley and Pickerill 1997, fig. 7C). Loading may have been triggered by rapid accumulation of sand within the fluvial channels.

The trace fossils in this association are hyporeliefs. They were produced as "resting" marks (Rusophycus) and rare bilobate trails (Cruziana), but not as basal expressions of shallow burrows dug through what is now the host sandstone. This means that they were formed after the scouring of the channel into the underlying floodplain mud but before deposition of sand in the channel and the sand's subsequent deformation due to loading. The exquisite detail of trace-fossil ornamentation that is preserved on the molding sandstone suggests that the producers were active when the mud substrate was firm. The predominant, generally deep-pit form of Rusophycus that is present might represent escape, concealment or aestivation.

\section{Ichnocoenosis I (Table 2, and Fig. 5)}

This ichnocoenosis comprises bilobate and simple interface trails (Didymaulichnus cf. lyelli and Helminthopsis hieroglyph ica) and burrows (Palaeophycus striatus Hall) encountered within, and on, $\geq 10 \mathrm{~m}$ thick grey sandstones of the Port Hood Fm. Several suites (e.g., Keighley and Pickerill 1997, fig. 3D) are found on parting surfaces within parallel or low-angle crossstratified fine- to medium-grained sandstones (occasionally with parting lineations). Suites from TF13a and TF18b occur in wave rippled sandstones that interbed or cap the crossstratified sandstone; relatively organic-rich ripple troughs are preferentially bioturbated. Architectural element analysis of these sandstones (Keighley and Pickerill 1996b) indicates that they formed as in-channel dune and bar deposits in a perennial fluvial system. Accordingly, the ichnocoenosis is interpreted to have formed on the downstream side of low relief, in-channel dunes during sedimentation from both upper- and lower-stage flow.

The shifting nature of the substrate and inferred episodic sedimentation suggests that the resident fauna was primarily opportunistic. Scavenging and filter feeding were likely 

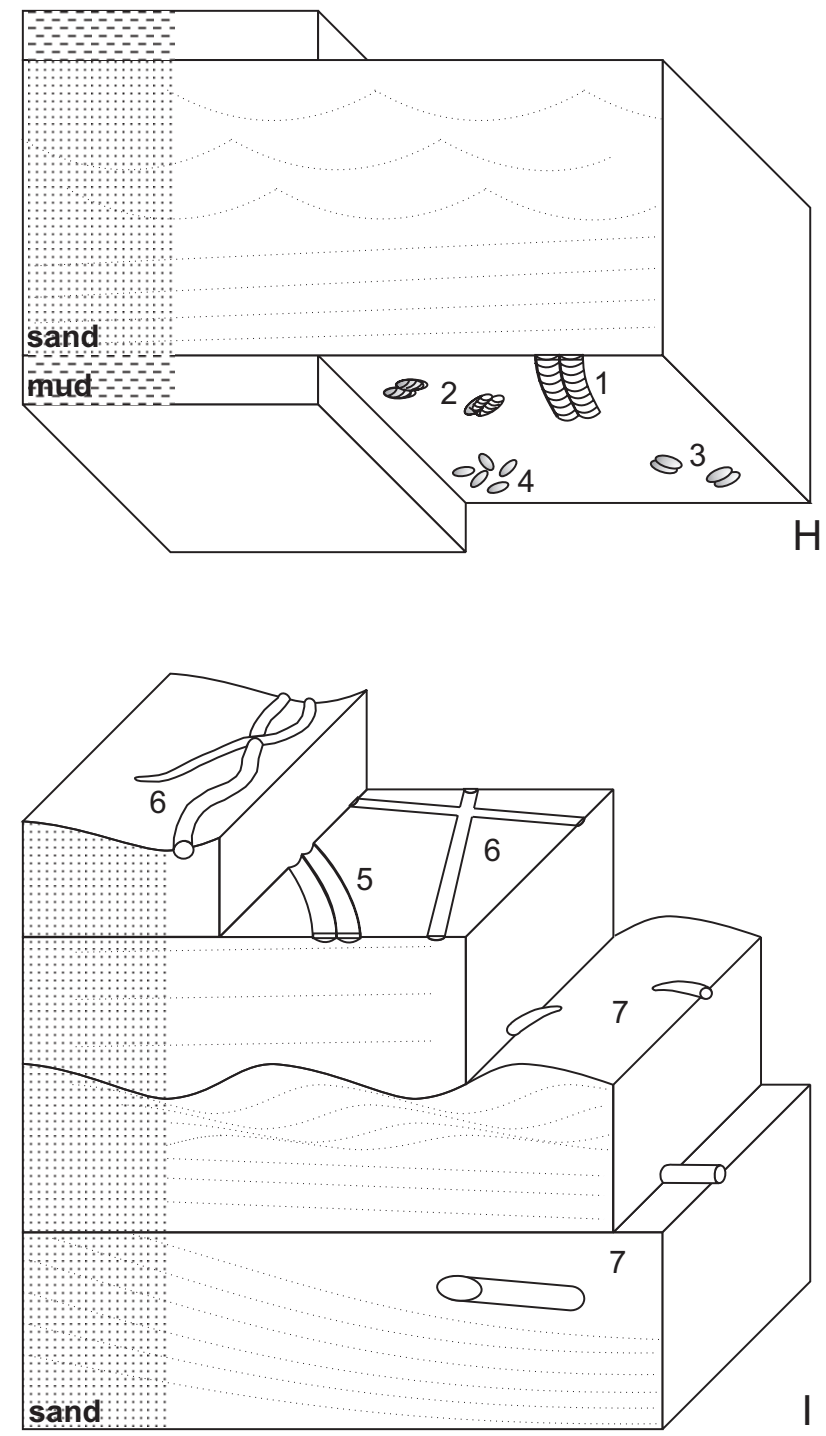

Fig. 5 Ichnocoenoses $\mathrm{H}$, and I: examples of trace fossils and their toponomic preservation. 1 = Cruziana problematica, 2 = Rusophycus carbonarius, 3 = cf. Rusophycus carbonarius, 4 = small ovate pits, type B, 5 = Didymaulichnus cf. lyelli, $6=\mathrm{Hel}$ minthopsis hieroglyphica, 7 = cf. Palaeophycus. See Keighley and Pickerill $(1997,1998)$ for details.

favoured activities of invertebrates particularly when upper flow regime conditions were maintained at length. The probable trace makers, arthropods such as branchiopod crustaceans, are potential producers of bilobate trails such as Didymaulichnus or unilobate trails such as Helminthopsis. Pickerill (1992) noted that these animals are mostly suspension feeders, though some are scavengers.

Didymaulichnus and Helminthopsis trail widths are consistently between 3-5 mm, identical with the widths of Rusophycus and sporadic Cruziana in ichnocoenosis H. Indeed, it may be simply the coarser grain size and less consolidated substrate during trail production that precludes preservation of a lateral ornamentation that would direct assignment of these narrow trails to Cruziana. The same producers might be responsible for the trails and marks both in this ichnocoenosis and ichnocoenoses $\mathrm{H}$. Behaviour is obviously different, since in this ichnocoenosis the focus is on directed (generally straight line) locomotion, and resting traces are not present.

\section{Ichnocoenosis J (Table 2, and Fig. 6)}

This ichnocoenosis comprises simple unbranched burrows (Planolites beverleyensis, Taenidium barretti) and rare systematically branched burrows (Phycodes pedum Seilacher), together with vertebrate trackways (types D and E of Keighley and Pickerill 1998). In most cases, the suites occur within fine- to medium-grained grey sandstones that interbed with grey mudstones and variably thick coal seams in the upper Port Hood Fm. TF12b is from a sandstone-dominated and coal-free succession in the lower Port Hood Fm. All suites are hosted toward and at the base of 0.15 to $1.0 \mathrm{~m}$ thick tabular sandstones. These grey sandstones, containing fossils of the clubmoss root Stigmaria, are low-angle cross-stratified or parallel laminated, and overlie $>0.5 \mathrm{~m}$ of dark grey, often coaly mudstone. The sandstones lack any indication of having been channelized or of radiating from a point source (i.e., crevasse splay deposits). Because of the associated coals, either a flood origin (sheet sands) on a swamp or a levee setting seems most likely.

Planolites and Phycodes burrows occur in full relief at the base of the sandstones (e.g., Keighley and Pickerill 1997, fig. $5 \mathrm{E}$ ), and formed following subaqueous deposition of at least a thin layer of sand onto the underlying mud. They were likely produced by organisms feeding on the underlying organic rich mud. The large Taenidium barretti of TF28a was also produced after the flood deposit. However, in this case, the producer was likely "escaping" from an unfavourable habitat after deposition of the sand. Though primarily horizontal, the burrow becomes vertical at one end, where the initial escape is assumed to have been made. The vertebrate trackway, type E, though preserved in hyporelief, likely represents undertracks, and the regular similar divergence of both left and right prints from the direction of travel suggests the producer was wading against a flood (Keighley and Pickerill 1998, fig. 7E). In contrast, other suites comprise the trackways of small vertebrates that would have been wading through nothing more than a few centimetres of water or have been traversing over the precursor muddy, swampy floodplain.

\section{Ichnocoenosis K(Table 2, and Fig. 6)}

This ichnocoenosis is represented exclusively by suite TF26a, which is itself a mono-ichnospecific entity of the surface pit Conichnus. The pits are preserved hypichnially on 10-30 $\mathrm{mm}$ thick, very-fine-grained grey sandstone that interbeds with thick grey mudstones. Because these mudstones are from the upper Port Hood Fm., they most likely represent a succession of quiet water, delta-top lacustrine deposits, whereas a 
storm- or flood-event deposit may be inferred for the host sandstone.

As previously noted for ichnocoenosis B, event deposits punctuate depositional settings that otherwise exist in equilibrium. The presence of these surface pits on the base of a possible event deposit suggests that the producers of the traces preferred the quiet water conditions and were disturbed, or mortified, by the conditions that produced the event bed. Conical trace fossils are typically equated with sessile, or hemisessile, epifaunal organisms (Pemberton et al. 1988) that feed from the water column in quiet conditions.

\section{Ichnocoenosis L (Table 2, and Fig. 6)}

This ichnocoenosis again consists only of one suite, namely TF26b, and the component trace fossils are exclusively sinusoidal surface trails (ichnospecies of Cochlichnus and Undichnus). It was observed from the top of the same sandstone (Keighley and Pickerill 1997, fig. 2C) that preserves ichnocoenosis K, and hence the same lacustrine setting is inferred. However, the two ichnocoenoses are not lumped together because of different trace fossil compositions and preservation.

Though this association occurs epichnially on an event bed, the producers are considered to have been established occupants of the event-disrupted ecosystem that were making initial reconnoitres subsequent to deposition of the event bed. Undichnus is interpreted to represent the swimming activity of fish (Anderson 1976). Cochlichnus, where not a backfilled burrow, may be the swimming activity of a vermiform animal, or a taphonomic variant of Undichnus.

\section{Ichnocoenosis M(Table 2, and Fig. 6)}

One burrow network of Thalassinoides suevicus (Rieth) represents this ichnocoenosis. It is located endichnially within an $\sim 10 \mathrm{~m}$ thick mudstone in the lower Port Hood Fm. This mudstone is primarily grey and soft-sediment deformed, as are the interbedded $\sim 30 \mathrm{~m}$ thick sandstones, but the host interval itself is mottled red-brown and retains a parallel to slightly undulatory lamination. Therefore, the interpreted depositional setting is that of a mostly waterlogged interfluve adjacent to low-sinuosity fluvial channels. The lack of any wall structure to the burrow suggests that it was constructed in firm sediment.

\section{ICHNOFACIES FOR NONMARINE STRATA}

One purpose for describing the depositional setting of the Cape Breton Island trace fossils in terms of their ichnocoenoses is so that they can then be compared with the latest ichnofacies models of Buatois and Mángano $(1995,1998)$ for the nonmarine realm. Our data also assist in the continued refinement of these models.
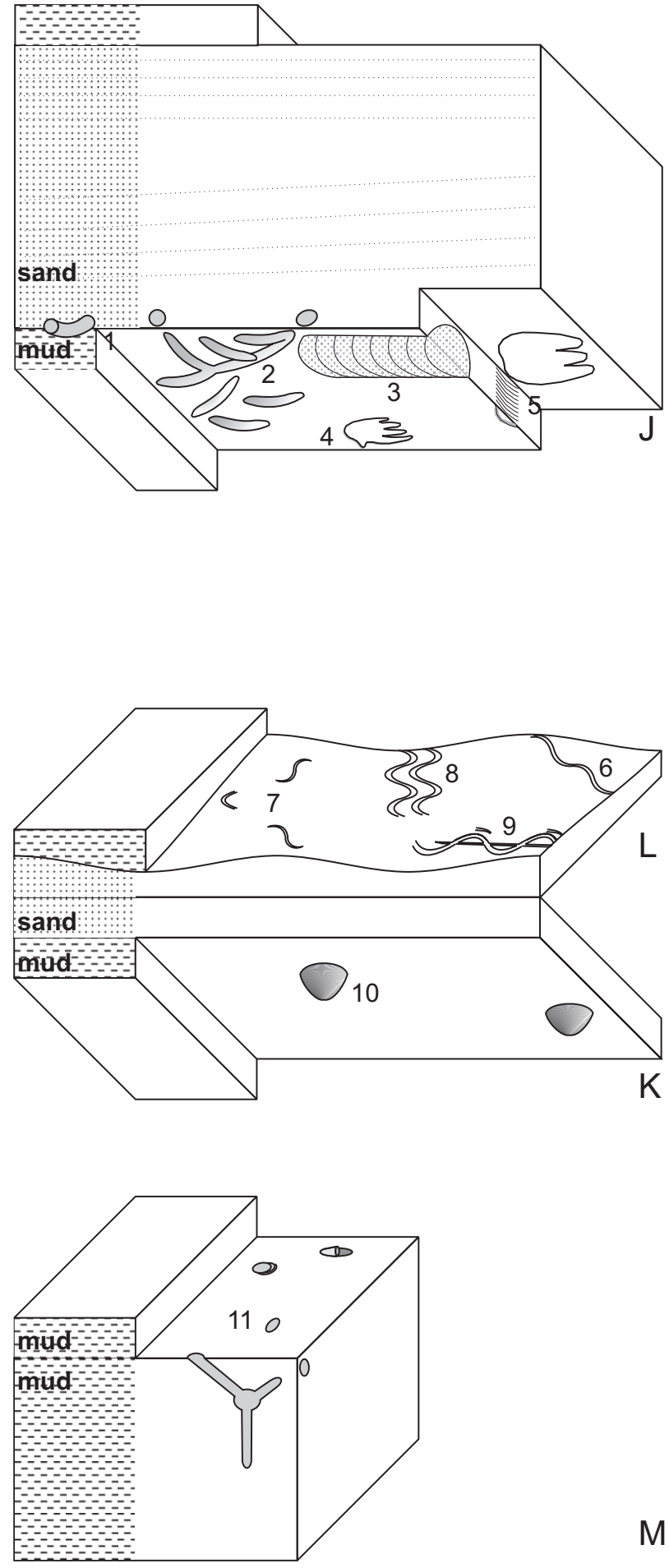

M

Fig. 6 Ichnocoenoses J, K, L, and M: examples of trace fossils and their toponomic preservation. 1 = Planolites beverleyensis, $2=$ Phycodes pedum, $3=$ Taenidium barretti, $4=$ vertebrate track(way), type $\mathrm{D}, 5$ = vertebrate track(way), type E, with undertracking, $6=$ Cochlichnus anguineus, $7=$ Cochlichnus isp., 8 = Undichnus binus, 9 = Undichnus consulcus, $10=$ Conichnus isp., 11 = Thalassinoides suevicus. See Keighley and Pickerill $(1997,1998)$ for details. 


\section{Existing ichnofacies}

Buatois and Mángano $(1995,1998)$ presented a model for the nonmarine realm that consisted of three archetypal ichnofacies unique to nonmarine strata (the Mermia-, Scoyenia-, and Termitichnus ichnofacies), as well as others also found in the marine realm, such as the Skolithos ichnofacies. Buatois and Mángano (1995, p. 151) included “...nonmarine, fully aquatic trace-fossil suites..." in their Mermia ichnofacies. The typical association was considered to have moderate to high ichnodiversity and abundance and to comprise dominantly (sub-)horizontal grazing and feeding traces and subordinate locomotion traces. Most of their examples correspond to systematic coverage branching burrow networks, migrating burrows, systematic coverage interface burrows and trails, irregular interface burrows and trails, simple non-striate pits, sinusoidal burrows and trails, simple burrows, and trackways (groups I to VIII in Tables 1 and 3).

These authors are the latest of several researchers to also offer a definition for the Scoyenia ichnofacies. The ichnofacies was originally introduced by (Seilacher 1967, p. 415) to correspond to "...non-marine sands and shales, often red beds, with a distinctive association of trace fossils" that were illustrated in Seilacher (1963, fig. 7). This association was of low diversity, comprising simple meniscate burrows, surface pits, and non-systematic coverage trackways and trails (subsequently recognized not to be very distinctive - e.g., Seilacher 1978; Frey et al. 1984). Unfortunately, the phrasing suggested that the presence of redbeds (and hence nonmarine strata) was implicit in the observation, rather than being simply one possible environmental interpretation. Subsequently, Frey et al. (1984) diagnosed the Scoyenia ichnofacies as being of low diversity with simple meniscate burrows predominant, but comprising few exclusive ichnotaxa. No environmental restriction was implied. However, continued emendations have indicated an environmental restriction. Bromley (1996) proposed that scratched and unscratched burrow margins were typical, and considered the Scoyenia ichnofacies the nonmarine "parallel" of the Glossifungites ichnofacies. In contrast, Buatois and Mángano $(1995,1998)$ considered the ichnofacies to be from softground transitional environments; marginal or ephemeral lacustrine settings, sheetflood, or fluvial settings. Within their "fluvio-lacustrine Scoyenia ichnofacies", component trace fossils may be described in morphologic terms as simple burrows, trackways, striate and bilobate pits, bilobate/trilobate burrows and trails, simple meniscate burrows, and vertical burrows (groups VII, VIII, X, XI, XII XIII in Tables 1 and 3). Buatois and Mángano (1998) additionally included sinuous trails and spreiten burrows (groups VI and IX). Associations dominated by trackways were included in the ichnofacies regardless of the presence or absence of meniscate burrows.

The Termitichnus ichnofacies of Smith et al. (1993) was initially introduced as an ichnocoenosis, since it was never demonstrated to have been "globally" recurrent. Although this deficiency was subsequently corrected by Buatois and Mángano (1995, table 4) the definition was subsequently con- sidered untenable (Genise et al., 2000). These latter authors, instead, proposed the Coprinisphaera ichnofacies, dominated by chambered (nesting) structures. They also suggested that a more restrictively defined Termitichnus ichnofacies might be established in the future.

The Skolithos ichnofacies has consistently been identified (e.g., Seilacher 1967; Ekdale et al. 1984; Bromley 1996) as being dominated by burrows with a vertical aspect, with or without spreite, and open burrow networks, commonly walled (groups XIII, XIV, XV in Tables 1 and 3). Meniscate and simple burrows (groups XII and VII) may also be preserved (Bromley 1996). The ichnofacies is generally interpreted to be indicative of littoral conditions that result in continuous cycles of erosion and deposition. Such cycles of erosion and deposition not only provide a taphonomic filter, but also a repetition of the same trace-fossil association overprinting itself (Bromley and Asgaard 1991). In contrast, Bromley and Asgaard (1991) suggested the presence of the Arenicolites ichnofacies where similar, but more diminutive morphologies are present, and where the vertical aspect burrows do not overprint one another.

Bromley (1996) has proposed that two other ichnofacies may be present in nonmarine strata, although neither has yet been shown to be recurrent. A potential Rusophycus ichnofacies would be dominated by bilobate trails and pits and by trackways. In the Buatois and Mángano $(1995,1998)$ model, such morphologies are currently included as part of the Scoyenia ichnofacies. The potential Fuersichnus ichnofacies would contain burrows with spreiten or spreiten-like structures. Buatois and Mángano (1998, p. 369) dismissed the Fuersichnus ichnofacies because "this ichnotaxon" had also been recorded in fluvial and floodplain depositional settings, making it an element of their "fluvio-lacustrine Scoyenia ichnofacies". However, morphological ichnofacies are defined by the trace-fossil content and are named after a typical, but not necessarily present (Frey et al. 1990) ichnotaxon of the component ichnocoenoses. Individual ichnotaxa and broader morphological groupings may also be encountered in more than one ichnofacies, as Buatois and Mángano $(1995,1998)$ have shown for simple burrows such as Planolites.

\section{Refinement of the nonmarine ichnofacies model}

The ichnocoenoses from Cape Breton Island, as well as those from the Carboniferous elsewhere in eastern Canada (examples 28 to 48 in Table 3D), do not all fit readily into the existing nonmarine ichnofacies model of Buatois and Mángano $(1995,1998)$. However, inclusion of eastern Canadian ichnocoenoses can be achieved within a refined model and emendations of the Scoyenia and Mermia ichnofacies definitions. (The Coprinisphaera ichnofacies is not currently relevant to eastern Canadian material.) This refined model also partly addresses the previously mentioned concerns of Goldring $(1993,1995)$, and the need to use "tiering" concepts to detail the conditions and chronology of the bioturbation (Frey and Goldring 1992). 
The Scoyenia and Mermia ichnofacies are not well defined, based on the example ichnocoenoses that are cited by Buatois and Mángano $(1995,1998)$ as supposedly being typical of the respective ichnofacies (Table 3A, B, and C). Buatois and Mángano (1995, table 3) included spreiten burrows within the Scoyenia ichnofacies and yet only one ichnotaxon (Fuersichnus), in a single ichnocoenosis, was provided as an example. This morphotype should be excluded from definitions of this ichnofacies until demonstrably recurrent. Similarly excluded should be sinusoidal burrows and trails (Group VI), because this morphotype is not encountered in ichnocoenoses that these authors include within the Scoyenia ichnofacies (Table 3C).

Sinusoidal burrows are widely recorded in examples of their Mermia ichnofacies (Table 3B). Simple systematic coverage interface burrows and simple irregular interface burrows are also present in most examples they assign to the Mermia ichnofacies (Table 3B). However, several of the ichnocoenoses they refer to (examples 6 to 9 in Table 3B) also contain additional morphotypes, namely bilobate pits, bilobate trails and/or predominant trackways, which are morphotypes these authors include as diagnostic of the Scoyenia ichnofacies.

Ichnocoenoses exemplifying the Scoyenia ichnofacies mostly contained meniscate burrows, with simple burrows, trackways, bilobate pits, bilobate trails and vertical burrows less common. However, Buatois and Mángano (1998, p. 369) again use example ichnocoenoses that contain morphotypes they do not consider typical of the ichnofacies. Some ichnocoenoses (examples 11 to 13, Table 3C) contain systematic-coverage interface burrows and trails, or irregular interface burrows and trails (group III or IV), morphotypes most common to the Mermia ichnofacies. Other ichnocoenoses (examples 23 to 27, Table 3C) contain vertical displacement shafts, branching burrow networks, and J-shaped and spiral burrows (groups XIV, $\mathrm{XV}, \mathrm{XVI}$ ) morphotypes most common to the Skolithos- and even Termitichnus ichnofacies.

When assessing ichnoceonoses from eastern Canada, there are several ichnocoenoses that can be readily assigned to the Scoyenia ichnofacies (examples 38 to 46, Table 3). However, as with examples given by Buatois and Mángano $(1995,1998)$, there are also several cases (examples 31 to 37 and 48, Table 3 ) that contain some morphotypes considered typical of both the Mermia- and Scoyenia ichnofacies. Which assignment is most appropriate?

One explanation for the occurrence of morphotypes characteristic of more than one ichnofacies but present in a single ichnocoenosis is that the host sediment body was subject to a change in environmental conditions while still at the surface. A fluctuation in base level would stimulate such change and alluvial-lacustrine basins can be prone to rapid base level rise or fall (references in Keighley et al., 2003). For example, in a lacustrine setting, a suite typical of the Skolithos ichnofacies (suite $\beta$ in Fig. 7A) may form in a bed separated from another bed containing a suite typical of the Scoyenia ichnofacies (suite $\alpha$ in Fig. 7A). Alternatively, following base-level fall, and basinward facies migration, an occurrence of suite $\beta$ may closely overlie suite $\alpha$ (Fig. 7B). Furthermore, if base level fall was rapid relative to sedimentation rate, all of the trace-fossil components may be encountered in the same rock unit and they will then appear to represent one, morphologically diverse association, $\gamma$, and hence one ichnocoenosis (Fig. 7C).

The ways in which ichnotaxa combine temporally to produce an ichnocoenosis such as $\gamma$, and recurrently as an ichnofacies, is the realm of ichnofabric analysis. Where cross-cutting relationships can be observed, it may be possible to determine that an ichnocoenosis is a composite of different trace-fossil suites and not contemporaneous tiers (Fig. 7E). If such occurrences can repeatedly be observed, an overprinting of the Scoyenia- and Skolithos ichnofacies has then been demonstrated and a mixed or composite ichnofacies can be constructed. An extension of the taphoseries concept (MacNaughton and Pickerill 1995; Keighley and Pickerill 1997) can then be applied: the particular ichnocoenosis is described as belonging to the composite ichnofacies but also to its taphonomic precursor ichnofacies. Potentially also, the order of ichnofacies production may be recognisable (with its potential for inferring base level rise or fall). Unfortunately, cross-cutting is not present in many cases (e.g., Fig. 7C); either due to insufficient maturity (sensu Bromley and Asgaard 1991) or possibly due to a trace-producer's aversion to cross-cutting. Thus, a taphoseries cannot be described. Without cross-cutting, it is difficult to determine whether there are separate suites, or a single diverse suite as in Fig. 7D. In this latter case, ichnologists have to accept that the fossil record may be inadequate for producing clearcut classifications.

To date, composite ichnofacies have been underutilized. However, in the marine realm, Bromley and Asgaard (1991) considered the Nereites ichnofacies to comprise a Zoophycos ichnofacies, and one or more as yet unnamed graphoglyptid ichnofacies. Recently, Uchman and Alvaro (2000) have demonstrated the overprinting of ichnocoenoses assigned to a stressed Mermia ichnofacies, a Scoyenia ichnofacies, and a Termitichnus ichnofacies (all sensu Buatois and Mángano 1998).

For the purpose of this study, we suggest that the Mermia ichnofacies should not be considered (from the present database) to be the name for a composite ichnofacies. Rather, it should be emended to represent ichnocoenoses comprising systematic coverage branching burrow networks, migrating burrows, systematic coverage interface burrows and trails, irregular interface burrows and trails, simple non-striate pits, sinusoidal burrows and trails, simple burrows, and trackways (groups I to VIII, Tables 1, 3). Systematic coverage-, and simple irregular interface burrows and trails should be predominant (groups III and IV), with trackways (group VIII) of limited abundance. In the current database, example ichnocoenoses include, in Table 3, examples 1 to 5 and 28 to 30 (including ichnocoenoses $\mathrm{K}$ and $\mathrm{L}$ from this study).

Accordingly, morphotypes of the Mermia ichnofacies are considered indicative of systematic grazing and locomotory behaviour, which correlates well with their occurrence in strata interpreted to have formed in quiet, low energy, permanently 


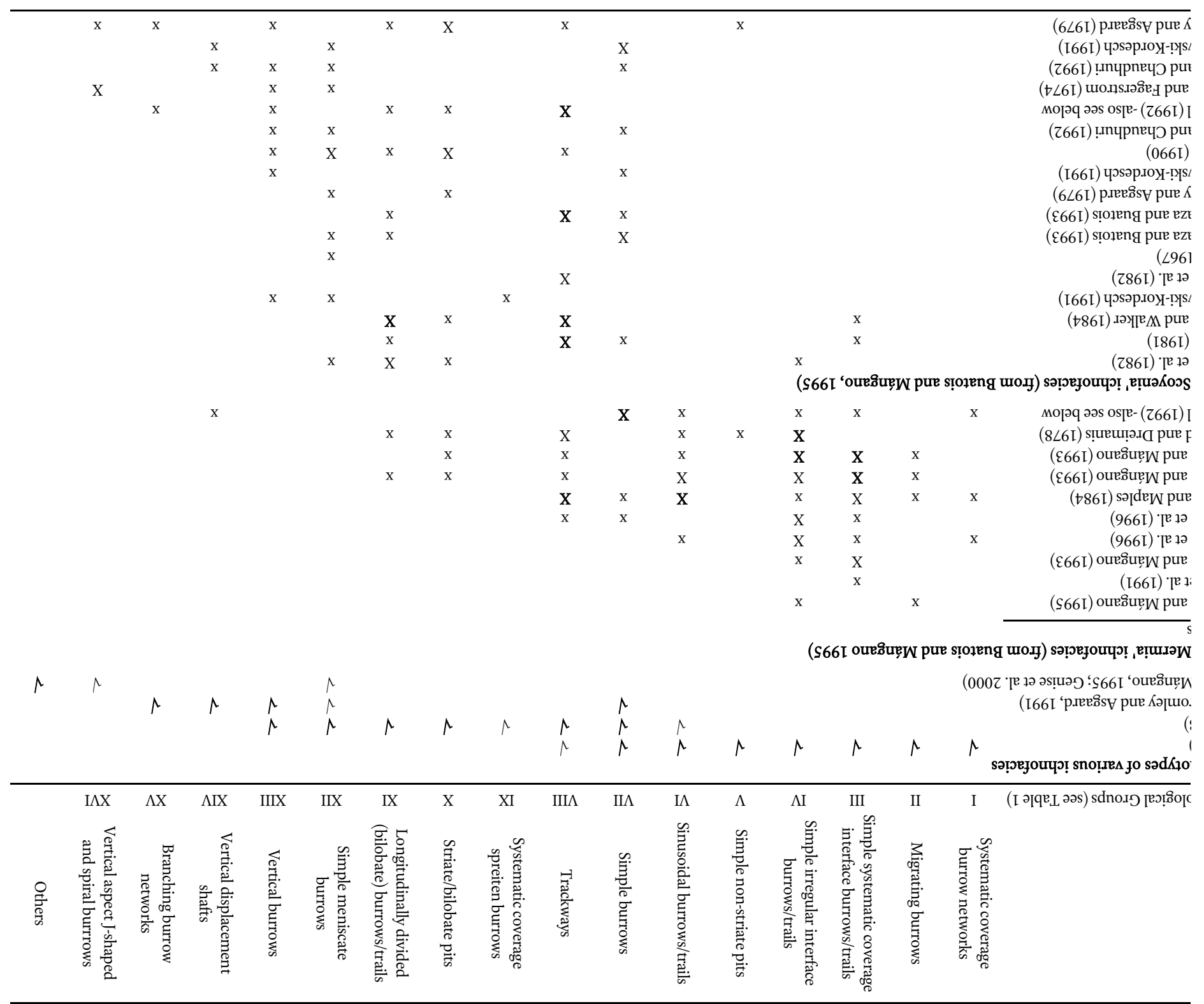

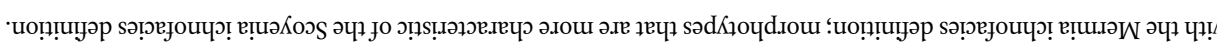

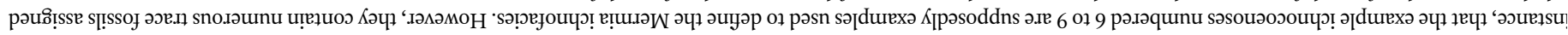

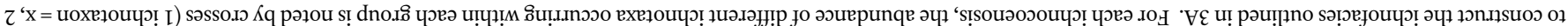

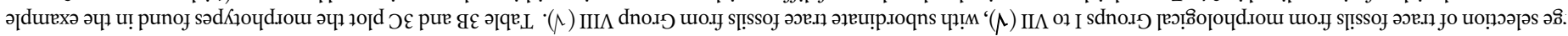

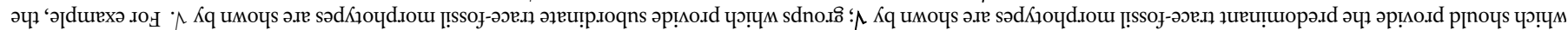

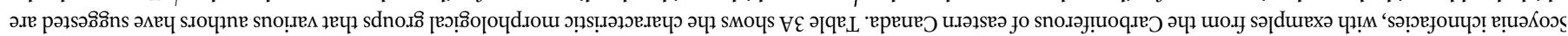



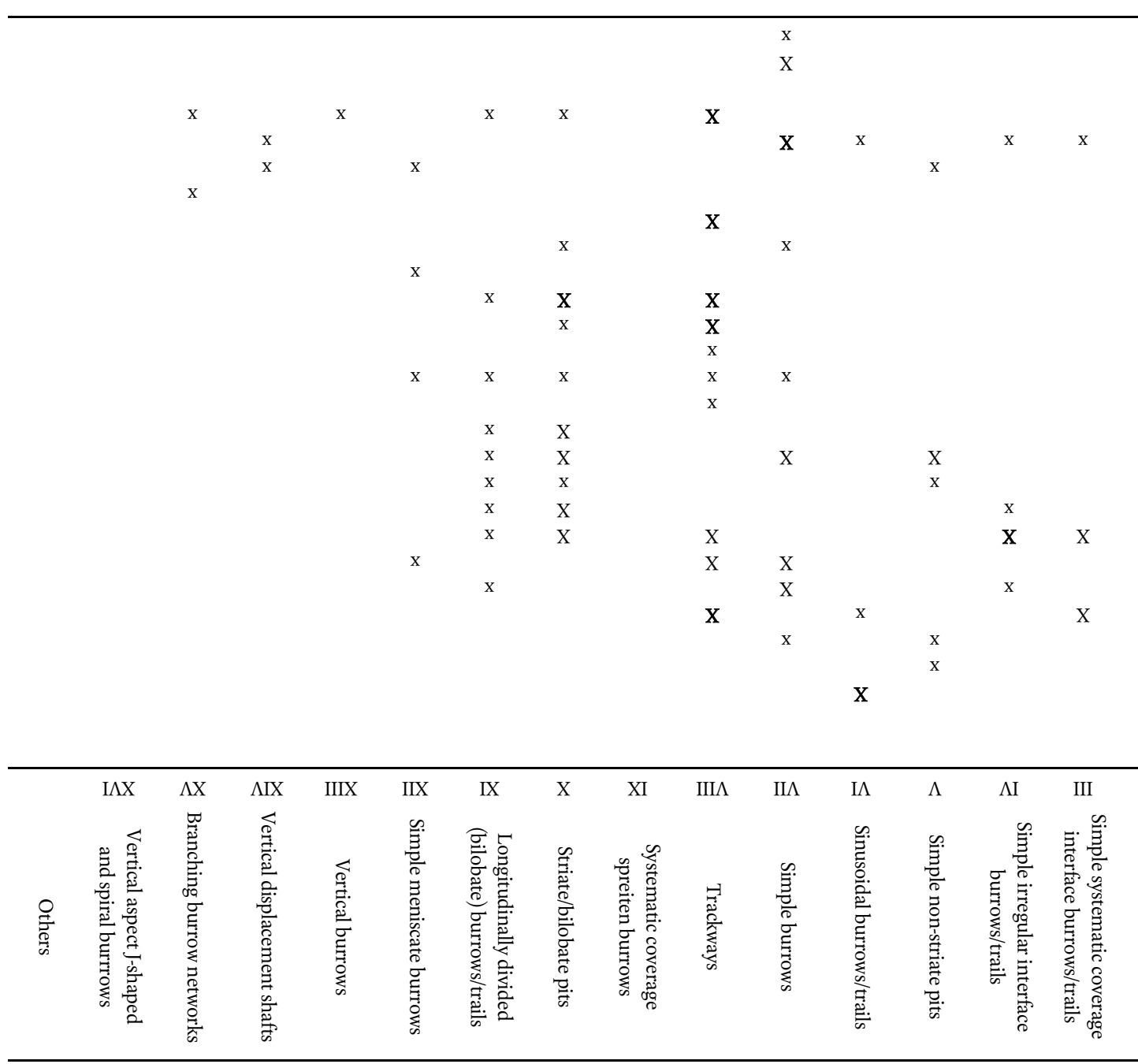


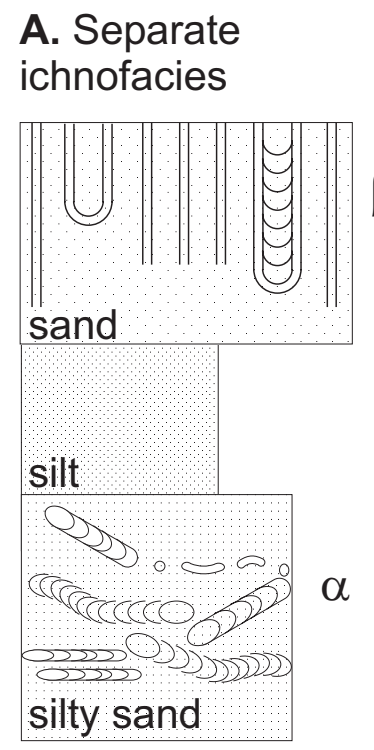
B. Adjacent ichnofacies
C. ???

D. One ichnofacies
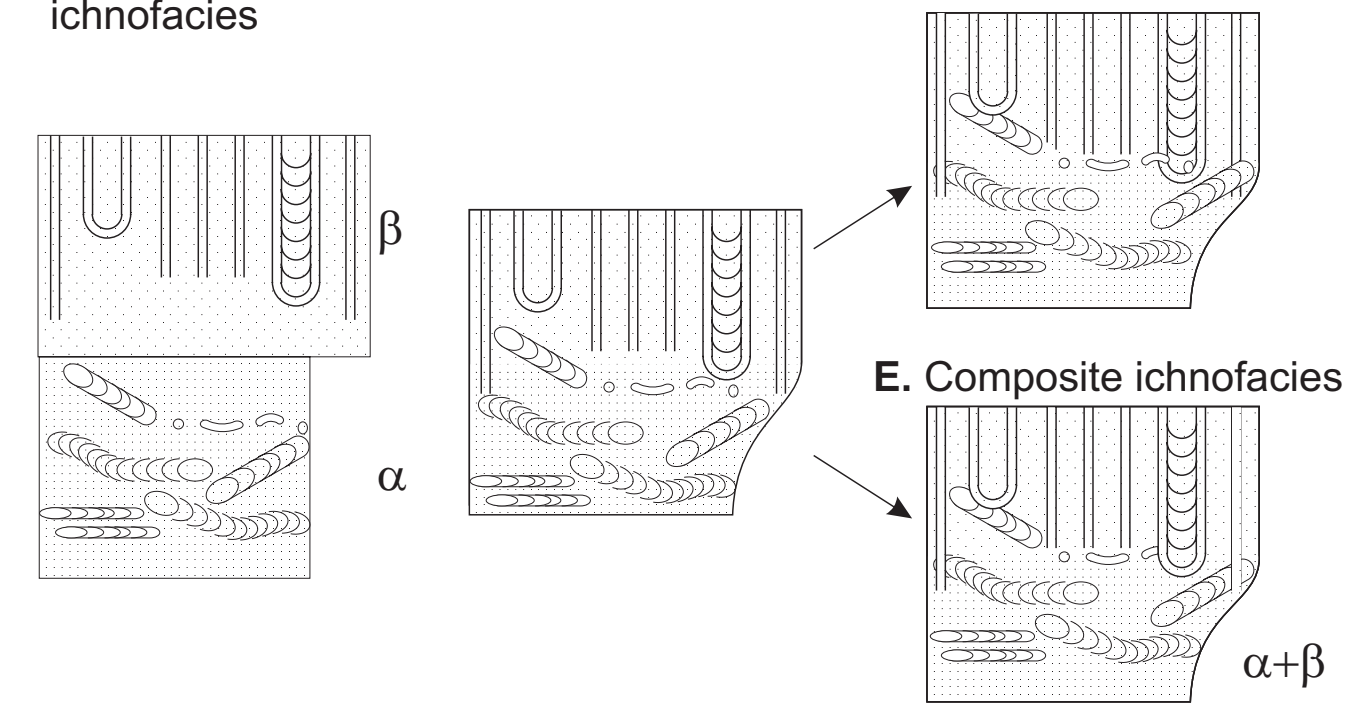

Fig. 7 Possible occurrence and identification of composite ichnofacies. (A) Two separate ichnocoenoses ( $\alpha$ and $\beta)$ that can be assigned to separate ichnofacies (e.g., the Scoyenia and Skolithos ichnofacies respectively). (B) Ichnocoenoses are still distinct, but their close physical proximity allows them to be considered "adjacent ichnofacies". (C) Morphotypes previously found in $\alpha$ and $\beta$ are now present in the same stratum. If overprinting relationships are observed during ichnofabric analysis it may be possible to determine whether the ichnocoenosis comprises one suite (D), where vertical burrows pre-date and post-date other burrows, or two suites juxtaposed (E), where vertical burrows always post-date other burrows. In E, the ichnocoenosis can be assigned to a composite of taphonomic precursor ichnofacies.

subaqueous settings (Buatois and Mángano 1995, 1998). Low energy levels enabled the deposition and potential accumulation of any organic matter that may have been suspended in the water column. Significant organic content permits systematic coverage of the substrate by animals to be a successful behavioural strategy (groups I to IV). Simple burrows (group VII), particularly Planolites, may also show dense coverage but may also be taphonomic successors of previously mentioned groups. The presence of shallow, surface-connected burrows may indicate limited oxygen in the substrate although the water column must have had sufficient oxygen levels to support a significant benthic community. Other morphotypes do not necessarily relate to high levels of substrate organic matter but only to significant organic matter in the water column. Sinuous trails represent mobile feeders, plug-shaped trace fossils likely indicate the presence of sessile freshwater carnivorous hydroids, feeding on zooplankton. Lockeia is usually interpreted as indicating the presence of bivalves (but see Maples and West 1989) that are mostly filter feeders (Clarkson 1993). These ichnotaxa reflect stable conditions with limited sedimentation; in unstable conditions, filter feeding is usually associated with the construction of vertical domichnia (Bromley 1990).

We also suggest that the Scoyenia ichnofacies should not be considered a composite ichnofacies. Instead, it should be emended to represent ichnocoenoses comprising simple burrows, trackways, striate and bilobate pits, bilobate/trilobate burrows and trails, simple meniscate burrows, and vertical burrows (groups VII, VIII, X, XI, XII XIII in Tables 1 and 3). Trackways, striate and bilobate pits, burrows, and trails, and meniscate burrows (groups VIII and X to XII) should be predominant, with vertical burrows (group XIII) of limited abundance. In the current database, the ichnocoenoses are those listed in Table 3 as examples 14 to 22 and 38 to 46 (including ichnocoenoses A, D, E, G, and $\mathrm{H}$ from this study).

The morphotypes of the Scoyenia ichnofacies are thought to indicate behaviours of opportunistic faunas in subaerial settings subject to inundation temporarily or periodically within the scale of the producing ichnofauna's individual lifespan (the transitional settings of Buatois and Mángano 1995, 1998). Low-energy environments need not equate with high organic accumulations if there is little biomass entering the system. Although this would preclude the presence of systematic grazers, organisms not prohibited from such environments would include a highly mobile, typically arthropod, epifauna that obtains food by scavenging or predation. Such a fauna would likely produce straight trackways, bilobate trails, and striate pits, - groups VIII, X and XI). For example, numerous arthropods, such as amphipod crustaceans (Wetzel 1983), are omnivorous, epifaunal, scavenging substrate feeders. Isopod crustaceans, being dorso-ventrally flattened, are also adapted for living on substrates exposed to moving water and higher energy settings (Pickerill 1992). Meniscate burrows (group XII), like resting traces (group X), represent mostly infaunal predation (Jensen 1990), scavenging, or fugichnial activity (from desiccation/salinity or temperature fluctuation/ 
predators/erosion). By commonly lacking a connection to the water/sediment interface, the burrows indicate an oxygenated substrate. The occurrence of simple burrows (group VII) in the Scoyenia ichnofacies may, in some cases, record the taphonomic successors of meniscate burrows.

Vertical burrows (group XIV), interpreted as the domichnia of filter feeders, scavengers or carnivores, are usually considered to represent ichnofaunas in high-energy settings (e.g., Buatois and Mángano 1995, 1998). Vertical constructions permit easy relocation after episodes of rapid sedimentation or erosion. Such burrows could also be produced in settings with fluctuating water tables, such as on fluvial bars. The producers may be attempting to stay above or below the water table, or adjusting to changes in water chemistry (Price and McCann 1990). When they are in association with vertical displacement shafts and branching burrow networks (groups XIV and XV) the vertical burrows are diagnostic of the Skolithos ichnofacies. Vertical burrows were also considered a secondary component of the Scoyenia ichnofacies by Buatois and Mángano (1995, 1998). In these situations, an interpretation of response to water chemistry or water table fluctuation is favoured. Vertical burrows occur in association with other morphotypes of the Skolithos ichnofacies as well as morphotypes characteristic of the Scoyenia ichnofacies in examples 23 to 27 and 48 of Table 3. In such cases, the vertical burrows (and those of groups XIV to XVI) may indicate production in higher energy settings, and their association with other Scoyenia morphotypes may represent a rapid environmental change in aqueous energy, or of submergence/emergence. Such examples may be considered composite ichnofacies.

There are also numerous ichnocoenoses in Table 3 that may represent the overprinting of trace fossils from low energy, permanently subaqueous settings (Mermia ichnofacies) by those from low energy, transitional settings (Scoyenia ichnofacies), or vice-versa, following base-level flux. These include examples 6 to 13 , as well as examples 31,35 , and 36 and ichnocoenoses $\mathrm{C}$, F, I, and J of this study. Additionally, although ichnocoenosis A places within the Scoyenia ichnofacies (Table 3D), it may alternatively be considered a composite ichnofacies. Specimens of Rusophycus from ichnocoenosis A could represent a low diversity occurrence of the Scoyenia ichnofacies, with the relatively dense coverage Planolites burrows representing a juxtaposed Mermia ichnofacies, since simple burrows (group VII) occur in both the Scoyenia- and Mermia ichnofacies. Unfortunately, all Planolites burrows have to be included together in the same morphological group because the pattern of coverage of burrows such as Planolites has never been considered to be a criterion (ichnotaxobase) for distinguishing morphologies. If such ichnotaxobases had ever been established, we would have expected that dense coverage of simple burrows equated with systematic coverage of organic-rich sediment in low energy conditions; and sparse coverage burrows equated to settings where organic accumulation was less.

Juxtaposed components of the Skolithos- and Mermia ichnofacies are also present. These ichnocoenoses include, in Table 3, examples 10, 24, 27, and ichnocoenosis B of this study. These occurrences might be considered to represent more extreme facies shifts.

Ichnocoenosis $\mathrm{M}$ is a unique ichnocoenosis in the current database and does not equate with any of the ichnofacies discussed in detail. It is speculated that it might be possible to include it within a revised Termitichnus ichnofacies.

\section{FUTURE WORK}

The above discussion allows for some refinement to be made to ichnofacies models for nonmarine strata, but it is unlikely all recurrent ichnocoenoses have been identified. Others may become apparent when a much more complete nonmarine database is examined. Also needed is a better delineation of existing ichnofacies, more precise distinction of morphological groups, and full recognition of composite ichnofacies. Just as the Coprinisphaera ichnofacies (Genise et al., 2000) was developed from the Termitichnus ichnofacies by analysis of a larger database, something akin to Bromley's (1996) hypothetical Fuersichnus ichnofacies might be split off from the Mermia ichnofacies, or his hypothetical Rusophycus ichnofacies identified as distinct from the Scoyenia ichnofacies.

Realistic interpretations of depositional setting from ichnofacies (Goldring 1993, 1995) are possible. Certainly, in the examples used in this report, no ichnofacies occurs exclusively within one single depositional setting. However, as suggested by Buatois and Mángano $(1995,1998)$, ichnocoenoses assigned to the (now emended) Mermia ichnofacies (Table 3) are certainly dominated by those interpreted to be subaqueous lacustrine. Ichnocoenoses assigned to the Scoyenia ichnofacies are dominated by those interpreted to be from transitional settings (Table 3). Better resolution from a larger database may, in future, permit subdivision of these settings and identification of environmental change by way of composite ichnofacies.

The question also remains as to whether the Mermia ichnofacies is indeed exclusive to nonmarine settings. Buatois and Mángano (1998) considered it the nonmarine equivalent of the Cruziana-, Zoophycos-, and Nereites ichnofacies in its environmental context, whereas Bromley (1996) considered it only equivalent to the Nereites ichnofacies. However, the association of morphotypes characteristic of the Mermia ichnofacies may be found to recur in marine strata, since none of its component morphotypes or individual ichnotaxa are considered to be exclusive to nonmarine strata.

\section{SUMMARY}

Sixty-six suites of trace fossils, from thirty-four different localities, have been collected or observed in the Carboniferous Mabou and Cumberland groups of western Cape Breton Island. Recurrent suites have been compiled into thirteen ichnocoenoses. Six ichnocoenoses are interpreted to have formed in various subaqueous (lacustrine) settings (ichnocoenoses $\mathrm{A}$, $\mathrm{B}, \mathrm{C}, \mathrm{F}, \mathrm{K}$, and L). Two ichnocoenoses (H and I) are interpreted 
to have formed in fluvial settings, and the remaining five (ichnocoenoses D, E, G, J, and M) in various parts of wet or dry floodplains.

The ichnocoenoses from Cape Breton Island, together with others described from the Carboniferous of the Maritimes, can be considered representative of two emended ichnofacies and their related composite ichnofacies. Ichnocoenoses $\mathrm{K}$ and $\mathrm{L}$ can be included within the Mermia ichnofacies, suggested to be an ichnofacies indicative of quiet, oxygenated, permanently subaqueous conditions with significant organic input. Ichnocoenoses D, E, G, and $\mathrm{H}$ can be included within the Scoyenia ichnofacies, suggested to be an ichnofacies indicative of transitional conditions, specifically quiet water, marginal lacustrine settings that regularly dried out, or periodically inundated floodplains. Ichnocoenoses A, B, C, F, I, and J have trace fossils considered typical of both the Mermia- and Scoyenia ichnofacies. This might indicate instances where the trace-fossil producers were environmentally tolerant and could inhabit both settings. Alternatively, the ichnocoenoses might represent cases where organisms from different environments juxtaposed or even overprinted their traces due to a change in environmental conditions. In the latter case, ichnocoenoses A, B, C, F, I, and J may be considered examples of composite ichnofacies that are taphonomic successors of some combination of the Mermia, Scoyenia, and Skolithos ichnofacies.

\section{ACKNOWLEDGEMENTS}

The journal-appointed referees, R. MacNaughton and J-P Zonneveld and journal co-editor R. Fensome are thanked for highly constructive criticisms. B. Broster, M. Gingras, C. Laury, D. McIlroy, R. Metz, A. Park, and P. Stringer also commented on earlier drafts. This work is an update of part of the $\mathrm{PhD}$ thesis of DGK that was funded by an NSERC research grant to RKP.

\section{REFERENCES}

Aceñolaza, F.G., \& Buatois, L.A. 1993. Nonmarine perigondwanic trace fossils from the late Palaeozoic of Argentina. Ichnos, 2, pp. 183-201.

Anderson, A.M. 1976. Fish trails from the Early Permian of South Africa. Palaeontology, 19, pp. 397-409.

Archer, A.W., \& MAPLEs, C.G. 1984. Trace fossil distribution across a marine-to-nonmarine gradient in the Pennsylvanian of Southwestern Indiana. Journal of Palaeontology, 58, pp. 448-466.

Archer, A.W., Calder, J.H., Gibling, M.R., Naylor, R.D., Reid, D.R., \& Wightman, W.G. 1995. Invertebrate trace fossils and agglutinated foraminifera as indicators of marine influence within the classic Carboniferous section at Joggins, Nova Scotia, Canada. Canadian Journal of Earth Sciences, 32, pp. 2027-2039.

Ausich, W.I., \& BotTJER, D.J. 1982. Tiering in suspension- feeding communities on soft substrata throughout the Phanerozoic. Science, 216, pp. 173-174.

Briggs, D.E.G., Plint, A.G., \& Pickerill, R.K. 1984. Arthropleura trails from the Westphalian of eastern Canada. Palaeontology, 27, pp. 843-855.

Bromley, R.G. 1990. Trace Fossils: Biology and Taphonomy. Special Topics in Palaeontology 3. Unwin Hyman, London, $280 \mathrm{p}$.

BromLEy, R.G. 1996. Trace Fossils: Biology and Taphonomy. 2nd Edition. Chapman and Hall, London, $340 \mathrm{p}$.

BRomLEy, R.G., \& AsGaARD, U. 1979. Triassic freshwater ichnocoenoses from Carlsberg Fjord, east Greenland. Palaeogeography, Palaeoclimatology, Palaeoecology, 28, pp. 39-80.

BRomLEY, R.G., \& AsGaARD, U. 1991. Ichnofacies: a mixture of taphofacies and biofacies. Lethaia, 24, pp. 153-163.

Buatois, L.A., \& Mángano, M.G. 1993. Trace fossils from a Carboniferous turbiditic lake: implications for the recognition of additional nonmarine ichnofacies. Ichnos, 2 , pp. 237-258.

Buatois, L.A., \& Mángano, M.G. 1995. The palaeoenvironmental and palaeoecological significance of the lacustrine Mermia ichnofacies: an archetypal subaqueous nonmarine trace fossil assemblage. Ichnos, 4, pp. 151-161.

Buatois, L.A., \& Mángano, M.G. 1998. Trace fossil analysis of lacustrine facies and basins. Palaeogeography, Palaeoclimatology, Palaeoecology, 140, pp. 367-382.

Buatois, L.A., Mángano, M.G., Wu, X., \& Zhang, G. 1996. Trace fossils from Jurassic lacustrine turbidites of the Anyao Formation (central China) and their environmental and evolutionary significance. Ichnos, 4, pp. 287-303.

Clarkson, E.N.K. 1993. Invertebrate Palaeontology and Evolution. $3^{\text {rd }}$ edition. Chapman and Hall, London, $434 \mathrm{p}$.

DörJes, J., \& Hertweck, G. 1975. Recent biocoenoses and ichnocoenoses in shallow-water marine environments. In The Study of Trace Fossils. Edited by R.W. Frey. Springer Verlag, New York, pp. 459-491.

Ekdale, A.A. 1985. Palaeoecology of the marine endobenthos. Palaeogeography, Palaeoclimatology, Palaeoecology, 50, pp. 63-81.

Ekdale, A.A., Pemberton, S.G., \& Bromley, R.G. 1984. Ichnology: Trace Fossils in Sedimentology and Stratigraphy. Society of Economic Palaeontologists and Mineralogists Short Course 15, 317 p.

ELLiotT, R.E. 1985. An interpretation of the trace fossil Cochlichnus kochi (Ludwig) from the East Pennine Coalfield of Britain. Proceedings of the Yorkshire Geological Society, 45, pp. 183-187.

Föllmi, K.B., \& GRIMm, K.A. 1990. Doomed pioneers: gravity-flow deposition and bioturbation in marine oxygen-deficient environments. Geology, 18, pp. 1069-1072.

Frey, R.W., \& Goldring, R. 1992. Marine event beds and recolonization surfaces as revealed by trace fossil analysis. Geological Magazine, 129, pp. 325-335.

Frey, R.W., \& Pemberton, S.G. 1985. Biogenic structures in outcrops and cores. I. Approaches to Ichnology. Bulletin of Canadian Petroleum Geology, 33, pp. 72-115. 
Frey, R.W., \& Seilacher, A. 1980. Uniformity in marine invertebrate ichnology. Lethaia, 13, pp. 183-207.

Frey, R.W., Pemberton, S.G., \& Fagerstrom, J.A. 1984. Morphological, ethological and environmental significance of the ichnogenera Scoyenia and Ancorichnus. Journal of Palaeontology, 58, pp. 511-518.

Frey, R.W., Pemberton, S.G. \& Saunders, T.D.A. 1990. Ichnofacies and bathymetry: a passive relationship. Journal of Palaeontology, 64, pp. 155-158.

Genise, J.F., Mángano, M.G., Buatois, L.A., Laza, J.H., \& VERDE, M. 2000. Insect trace fossil associations in palaeosols: the Coprinisphaera ichnofacies. Palaios, 15, 49-64.

Gibbard, P.L., \& Dreimanis, A. 1978. Trace fossils from late Pleistocene glacial lake sediments in southwestern Ontario, Canada. Canadian Journal of Earth Sciences, 15, pp. 1967-1976.

Gibling, M.R. 1995. Upper Palaeozoic rocks, Nova Scotia. In Chapter 5 of Geology of the Appalachian-Caledonian Orogen in Canada and Greenland. Edited by H. Williams. Geological Survey of Canada, Geology of Canada, 6, pp. 493-523.

GIERLOWSKI-KoRDESCH, E. 1991. Ichnology of an ephemeral lacustrine/alluvial plain system: Jurassic East Berlin Formation, Hartford Basin, USA. Ichnos, 1, pp. 221-232.

GolDRING, R. 1993. Ichnofacies and facies interpretation: Palaios, 8, pp. 403-405.

GolDRING, R. 1995. Organisms and the substrate: response and effect. In Marine Palaeoenvironmental Analysis from Fossils. Edited by D.W.J. Bosence \& P.A. Allison. Geological Society, London, Special Publication No. 83, pp. 151-180.

HAMBLIN, A.P. 1992. Half-graben lacustrine sedimentary rocks of the lower Carboniferous Strathlorne Formation, Horton Group, Cape Breton Island, Nova Scotia, Canada. Sedimentology, 39, 263-284.

Hamblin, A.P. 2001. Stratigraphy, sedimentology, tectonics, and resource potential of the Lower Carboniferous Mabou Group, Nova Scotia. Geological Survey of Canada Bulletin, $568,166 \mathrm{p}$.

Han, Y., \& Pickerill, R. 1994. Palichnology of the Lower Devonian Wapske Formation, Perth-Andover-Mount Carleton region, northwestern New Brunswick, eastern Canada. Atlantic Geology, 30, 37-46.

InTERnATIONAL COMmission on Zoological NomenclaTURE (I.C.Z.N.). 1985. International Code of Zoological Nomenclature. (3rd edition Adopted by the 20th General Assembly of the International Union of Biological Sciences, 1985). International Trust for Zoological Nomenclature in association with the British Museum (Natural History), London, and University of California Press, Berkeley and Los Angeles, $338 \mathrm{p}$.

Jensen, S. 1990. Predation by early Cambrian trilobites on infaunal worms - evidence from the Swedish Mickwitzia Sandstone. Lethaia, 23, pp. 29-42.

KeIGHLEY, D.G. 1996. The stratigraphy, sedimentology, and ichnology of the Mabou Group and Cumberland Group (middle Carboniferous), western Cape Breton Island, east- ern Canada. Unpublished PhD thesis, University of New Brunswick, $704 \mathrm{p}$.

Keighley, D.G., \& Pickerill, R.K. 1994. The ichnogenus Beaconites, and its relationship to Ancorichnus and Taenidium. Palaeontology, 37, pp. 305-337.

Keighley, D.G., \& PickeriLl, R.K. 1995. Commentary: the ichnotaxa Palaeophycus and Planolites, historical perspectives and recommendations. Ichnos, 3, pp. 301-309.

Keighley, D.G., \& Pickerill, R.K. 1996a. Small compound Cruziana, Rusophycus, and related ichnotaxa: the nomenclatural debate and systematic ichnology, with examples from eastern Canada. Ichnos, 4, pp. 261-285.

Keighley, D.G., \& Pickerill, R.K. 1996b. The evolution of fluvial systems in the Port Hood Formation (Upper Carboniferous), western Cape Breton Island, eastern Canada. Sedimentary Geology, 106, pp. 97-144.

Keighley, D.G., \& Pickerill, R.K. 1997. Systematicichnology of the Mabou and Cumberland Groups (Carboniferous) of western Cape Breton Island, eastern Canada, 1: Burrows, pits, trails, and coprolites. Atlantic Geology, 33, pp. 181-215.

Keighley, D.G., \& Pickerill, R.K. 1998. Systematic ichnology of the Mabou and Cumberland Groups (Carboniferous) of western Cape Breton Island, eastern Canada, 2: surface markings. Atlantic Geology, 34, pp. 83-112.

Keighley, D.G., Flint, S., Howell, J., \& Moscariello, A. 2003. Sequence stratigraphy in lacustrine basins: a model for part of the Green River Formation, southwest Uinta Basin, Utah, USA. Journal of Sedimentary Research, 73, pp. 987-1006.

LOCKLEY, M.G., Rindsberg, A.K., \& ZeILER, R.M. 1987. The palaeoenvironmental significance of the nearshore Curvolithus ichnofacies. Palaios, 2, 255-262.

Lockley, M.G., Hunt, A.P., \& Meyer, C.A. 1994. Vertebrate tracks and the ichnofacies concept: implications for palaeoecology and palichnostratigraphy. In The Palaeobiology of Trace Fossils. Edited by S.K. Donovan. John Wiley and Sons, Chichester, pp. 241-268.

MacNaughton, R.B., \& Pickerill, R.K. 1995. Invertebrate ichnology of the nonmarine Lepreau Formation (Triassic), southern New Brunswick, eastern Canada. Journal of Palaeontology, 69, pp. 160-171.

Maples, C.G., \& West, R.R. 1989. Lockeia, not Pelecypodichnus. Journal of Palaeontology, 63, pp. 694-696.

Martel, A.T., \& Gibling, M.R. 1991. Wave-dominated lacustrine facies and tectonically controlled cyclicity in the Lower Carboniferous Horton Bluff Formation, Nova Scotia, Canada. In Lacustrine Facies Analysis. Edited by P. Anadon, L. Cabrera \& K. Kelts. International Association of Sedimentologists Special Publication, 13, pp. 223-243.

Metz, R. 1987. Insect traces from nonmarine ephemeral puddles. Boreas, 16, pp. 189-195.

Middleton, G.V. 1978. Facies. In Encyclopedia of Sedimentology. Edited by R.W. Fairbridge \& J. Bourgeois. Dowden, Hutchinson and Ross, Stroudsburg, Pa. pp. 323-325.

Miller, M.F., Collinson, J.W., \& Frisch, R.A. 1991. Depositional setting and history of a Permian black shale: 
MacKellar Formation, Central Transantarctic Mountains. In Gondwana Seven Proceedings. Edited by H. Ulbrich \& A.C. Rocha Campos. Seventh International Gondwana Symposium, São Paulo, pp. 201-215.

Pemberton, S.G., Frey, R.W., \& Bromley, R.G. 1988. The ichnotaxonomy of Conostichus and other plug-shaped ichnofossils. Canadian Journal of Earth Sciences, 25, pp. 866-892.

PICKERILL, R.K. 1992. Carboniferous nonmarine invertebrate ichnocoenoses from southern New Brunswick, eastern Canada. Ichnos, 2, pp. 21-35.

PICKerill, R.K. 1994. Nomenclature and taxonomy of invertebrate trace fossils. In The Palaeobiology of Trace Fossils. Edited by S.K. Donovan. John Wiley and Sons, Chichester, pp. 3-42.

Pollard, J.E. 1981. A comparison between the Triassic trace fossils of Cheshire and south Germany. Palaeontology, 24, pp. 555-588.

Pollard, J.E., \& Walker, E.F. 1984. Reassessment of sediments and trace fossils from Old Red Sandstone (Lower Devonian) of Dunure, Scotland, described by John Smith (1909). Géobios, 17, pp. 567-576.

Pollard, J.E., Steel, R.J., \& Undersrud, E. 1982. Facies sequences and trace fossils in lacustrine/fan delta deposits, Hornelen Basin (M. Devonian), western Norway. Sedimentary Geology, 32, pp. 63-87.

Price, S., \& McCanN, T. 1990. Environmental significance of Arenicolites ichnosp. in Pliocene lake deposits of southwest Turkey. Neues Jahrbuch für Geologie und Paläontologie, Monatshefte, 1990, pp. 687-694.

REAding, H.G. 1978. Sedimentary Environments and Facies. Blackwell Scientific Publications, Oxford, 569 p.

RYAN, R.J. 1986. Fossil myriapod trails in the Permo-Carboniferous strata of northern Nova Scotia, Canada. Maritime Sediments and Atlantic Geology 22, pp. 156-161.

SARJEANT, W.A.S., \& Mossman, D.J. 1978. Vertebrate footprints from the Carboniferous sediments of Nova Scotia: a historical review and description of newly discovered forms. Palaeogeography, Palaeoclimatology, Palaeoecology, 23, pp. 279-306.
Sarkar, S., \& Chaudhuri, A.K. 1992. Trace fossils in Middle to Late Triassic fluvial redbeds, Pranhita-Godavari Valley, South India. Ichnos, 2, pp. 7-19.

SeIlacher, A. 1963. Lebensspuren und Salinitätsfazies. Fortschritte in der Geologie von Rheinland und Westfalens, 10, pp. 81-94.

SeILACHER, A. 1964. Biogenic sedimentary structures. In Approaches to Palaeoecology. Edited by J. Imbrie \& N. Newell. Wiley, New York, pp. 296-316.

SeILACHER, A. 1967. Bathymetry of trace fossils. Marine Geology, 5, pp. 413-428.

SEILACHER, A. 1978. Use of trace fossil assemblages for recognizing depositional environments. In Trace Fossil Concepts. Edited by P.B. Basan. Society of Economic Palaeontologists and Mineralogists, Short Course No. 5, pp. 167-181.

Smith, R.M.H., MAson, T.R., \& Ward, J.D. 1993. Flash-flood sediments and ichnofacies of the Late Pleistocene Homeb Silts, Kuiseb River, Namibia. Sedimentary Geology, 85, pp. 579-599.

Stanley, K.O., \& Fagerstrom, J.A. 1974. Miocene invertebrate trace fossils from a braided river environment, Western Nebraska, U.S.A. Palaeogeography Palaeoclimatology Palaeoecology, 15, pp. 63-82.

Tоотs, H. 1967. Invertebrate burrows in the non-marine Miocene of Wyoming. Contributions to Geology, 6, pp. 93-96.

Uchman, A., \& Alvaro, J.J. 2000. Non-marine invertebrate trace fossils from the Tertiary Calatayud-Teruel Basin, NE Spain. Revista Espanola de Palaeontologia, 15, pp. 203218.

Wetzel, R.G. 1983. Limnology. 2nd Edition. Saunders College Publishing, New York, $767 \mathrm{p}$.

Woolfe, K.J. 1990. Trace fossils as palaeoenvironmental indicators in the Taylor Group (Devonian) of Antarctica. Palaeogeography, Palaeoclimatology, Palaeoecology, 80, pp. 301-310.

Editorial responsibility: Robert A. Fensome 